\title{
DE VRAAGSTELLING IN VOLKSRAADPLEGINGEN EN REFERENDA
}

\author{
Door Jaak BILLIET ${ }^{*}$
}

Gewoon Hoogleraar aan het Departement Sociologie van de Katholieke Universiteit Leuven

\section{Inleiding}

De vraagstelling, inbegrepen de wijze waarop de burger een keuze moet maken op basis van een antwoordschaal, is een cruciaal gegeven in elke volksraadpleging, zowel in een bindend consultatief of correctief referendum als in een adviserende raadpleging Bij het doornemen van wettelijke regelingen, voorstellen, commentaren, en wetenschappelijke studies over het referendum valt het op hoe bijzonder weinig over de vraagstelling en de antwoordmogelijkheden gehandeld wordt. Als er in de teksten van juridische aard al iets over de vraagstelling te vinden is, dan is dat vrijwel uitsluitend over de bevoegdheid om de vragen te formuleren (een wetgevend orgaan of de initiatiefnemers), over de ontvankelijkheid van de vragen, en over hooguit enkele kenmerken van de vraag (gesloten ja/neen, vragen met eenheid van onderwerp, geen dubbele negatie). Zo ook in de Nota van de Juridische Dienst van de Kamer van Volksvertegenwoordigers over de probleempunten in verband met de rechtstreekse democratie. ${ }^{1}$ Weliswaar wordt daar van een controle gewaagd door een onafhankelijke instantie $^{2}$, maar het voorbeeld dat daar onmiddellijk op volgt doet vermoeden dat hier vooral een controle op de ontvankelijkheid bedoeld wordt.

Men krijgt bijgevolg de indruk dat de verwoording van een vraag, het begrijpen daarvan door de burger, en het kiezen van een antwoord dat het best zijn of haar opinie weergeeft, niet problematisch zou zijn. Hier en daar vindt men wel een expliciete verwijzing naar de verwarring omwille van de vraagstelling. Zo bijvoorbeeld in het verslag van de Hoorzitting met de Vlaamse Adviescommissie voor Volksraadplegingen in de Commissie voor Binnenlandse Aangelegenheden, Stadsvernieuwing en Huisvesting van het Vlaams Parlement. ${ }^{3}$ Het probleem van de misleidende vraagstelling wordt daar zowel naar voor gebracht door de voorzitter van de Adviescommissie als door de onderzoekers (van de VUB) die gehoord werden over de exit-poll naar aanleiding van de Gentse volksraadpleging van 14 december 1997. ${ }^{4}$ Er worden daar ook voorstellen gedaan voor een betere controle. De relatief geringe aandacht ${ }^{5}$ voor de vraagstelling staat alleszins in schril contrast met zeer gespecialiseerde literatuur

\footnotetext{
${ }^{*}$ Deze studie is ontstaan n.a.v. mijn werkzaamheden in de Wetenschappelijke Commissie Politieke Vernieuwing van Kamer en Senaat.

${ }^{1}$ DOC 50. 0797/0001 (Kamer) en 2-416/1 (Senaat), 88-89.

${ }^{2}$ Met verwijzing naar de Vlaamse Adviescommissie voor volksraadplegingen ${ }^{2}$ die werd opgericht bij besluit van de Vlaamse regering van 8 juli 1997.

${ }^{3}$ Vlaams Parlement. Stuk 1115 (1997-1998) - Nr. 1.

${ }^{4}$ Ibid., 5, 6, 7, 8,12, 20.

${ }^{5}$ Er zijn uitzonderlijk ook wel voorbeelden waarin bijzonder veel aandacht wordt besteed aan de "klare" formulering van een bepaalde vraag. Dat is het geval in de zgn. 'Bill on Clarity' (Bill C-20) van het federale House of Commons in Canada over de vraag naar onafhankelijkheid van Quebec. Het begrip "klaarheid" (en éénduidigheid) slaat hier zowel op de verwoording van de vraag als op de grootte van de meerderheid. Zie o.m. 'Notes for an Address by the President of the Privy Council and Minister of Intergovernmental Affairs the Honorable Stéphane Dion on the Second Reading of Bill C-20', House of Commons, Ottawa, Ontario, December 14, 1999.
} 
over het problematisch karakter van het beantwoorden van opinievragen in het domein van de methodologie van het opinieonderzoek. ${ }^{6}$ Het is hoofdzakelijk vanuit die discipline dat wij de vraagstelling zullen benaderen.

\section{De vraagstelling in wetenschappelijke studies en in reacties van betrokkenen}

\section{A. Wetschappelijke studies}

Het probleem van de vraagstelling is natuurlijk niet helemaal afwezig in de wetenschappelijke literatuur over referenda, maar daar wordt het vlug gesteld in het licht van de discussie tussen de voorstanders en de tegenstanders, en vermeld onder de mogelijke nadelen. Zo vindt men in het standaardwerk van Butler en Ranney "Referenda around the World" de verwijzing naar verschillende Amerikaanse studies waarin wordt gesteld dat de vragen vaak zo verwoord zijn dat een "Ja" stem in feite een stem tegen een specifieke beleidsmaatregel is. Indien men dus voor het invoeren van de maatregel is zou men "neen" moeten stemmen. Zulke vragen zijn tevens verwarrend omwille van de zgn. "dubbele negatie". Als gevolg daarvan zou volgens een bekende studie van Magleby ${ }^{8}$ waarin de participatie en de mate van geïnformeerd zijn van de burgers onderzocht wordt, in een aantal gevallen van 10 tot 20 procent "foute" antwoorden gegeven worden (d.i. burgers die voor de maatregel zijn stemmen "Ja" in plaats van "Neen"). Er wordt echter aan toegevoegd dat dit niet tot verkeerde besluiten heeft geleid bij maatregelen waarover duidelijke preferenties onder de burgers bestaan.

Er wordt veel verwezen naar de werken van Magleby om het problematisch karakter van referenda aan te kaarten, onder meer omdat het kiezen van een antwoord gecompliceerder wordt geacht dan de keuze van kandidaten bij verkiezingen (we komen hier nog op terug), en omdat uit onderzoek zou blijken dat het vormen van een opinie tijdens de campagne voor een referendum, problematisch is omwille van het laag kennisniveau van de deelnemers. . Een ander thema dat in de wetenschappelijke literatuur veel aandacht krijgt, heeft te maken met de wijze van vaststellen van een meerderheid indien méér dan twee antwoordalternatieven worden voorgelegd aan de kiezers (voortaan "deelnemers" ge-

\footnotetext{
${ }^{6}$ Voor een recent overzicht zie: J. BLLIET, De publieke opinie ondervraagd. Over de zin en onzin van opiniepeilingen, in B. RAYMAEKERS en A. VAN DE PUTTE (red.), Krachten voor de toekomst. Lessen voor de eenentwintigste eeuw. Leuven, Universitaire Pers/Davidsfonds, 2000, 243-283. Een paar zeer relevante studies zijn: B. HOLLEMAN, The forbid/allow assymetry. On the cognitive mechanisms underlying wording effects in surveys. Utrecht Studies in Language and Communication, Amsterdam, Atlanta, 2000; J.R. ZALLER, The Nature and Origins of Mass Opinion. Cambridge, Cambridge University Press, 1992.

${ }^{7}$ D. BUTLER, en A. RANNEY, Referenda around the World. The growing use of direct democracy. London, MacMillan, 1994, 18.

${ }^{8}$ D. MAGLEBY, Direct Legislation: Voting on Ballot Propositions in the United States. Baltimore, John Hopkins University Press, 1984.

9 Zie: D.B. MaGlebY, Opinion formation and oinion change in ballot proposition campaigns, in: M. MARGolis and G.A. MAuser (Eds.), Manipulating public opinion. Belmont, Cole Pub. Co, 1989, 103. Onderzoek in Nederland komt echter tot een andere conclusie wat de aandacht voor de campagne aangaat. Zie P. Nejuens, M. Minkman en J. SLOT, Opinion Formation in Referendum Campaigns. A Study of the Amsterdam Referenda, in: Acta Politica, 33 (1998), 300-316. Bij die studie moet men echter voor ogen houden dat hier mogelijks enige overschatting van de betrokkenheid en aandacht plaats heeft omdat de medewerking aan de enquêtes als zodanig al laag is (tussen $48 \%$ en $66 \%$ ). Lager geschoolden antwoorden minder op enquêtes. Er werd echter wel gecorrigeerd door te wegen naargelang van deelname aan het referendum en de laatste gemeenteverkiezingen.
} 
noemd). ${ }^{10}$ Verscheidene van deze aspecten zijn ook aan de orde in de studies van De Geest ${ }^{11}$ en Gilhuis. ${ }^{12}$ Deze komen verder uitvoerig ter spake.

\section{B. Voor en -tegenstanders}

De verwoording van de vraag is regelmatig aan de orde in populaire publicaties van de betrokkenen die vrijwel na elk referendum verschijnen. Het aantal publicaties is te omvangrijk om te vermelden en we kunnen ons beperken tot het overzicht van een aantal gemeentelijke volksraadplegingen in $\mathrm{De} G e$ meente. ${ }^{13}$ In minstens vijf van de 24 behandelde gevallen wordt een probleem van vraagverwoording gesignaleerd (Gent, Riemst, Waasmunster, Merchtem, Poperinge). Hierbij moet men bedenken dat in een aantal gevallen de verwoording niet eens aan de orde was aangezien de rechtmatigheid van de vraag werd betwist. Betwistingen over de vraagstelling vind men ook in een aantal Nederlandse publicaties over het verloop van referenda. ${ }^{14}$ In de meeste van die gevallen wordt de vraagstelling besproken vanuit het aspect "manipulatie", waarbij gedacht wordt aan een weloverwogen verwoording met als bedoeling de antwoorden in een gewenste richting te sturen.

Soms wordt het probleem van de manipulatie via de vraagverwoording sterk gerelativeerd. Volgens Verhulst stelt het probleem van gemanipuleerde vraagstelling zich zelden of nooit op plaatsen waar volksinitiatieven met enige regelmaat voorkomen. De naamgeving van het referendum en de opstelling van de officiële kiesbrochure zouden volgens deze auteur in staten als Zwitserland, Californië, Oregon of Washington door neutrale diensten gebeuren die scrupuleus toezien op de onpartijdigheid en de transparantie van de vraagstelling. In Zwitserland wordt ook toegezien op het al dan niet misleidend karakter van de naam van het volksinitiatief. In zijn voorbeelden vermeldt Verhulst, die een notoir voorstander van referenda en volksinitiatieven is, het probleem van de omwisseling van "ja" en "neen", en het protest daartegen (in Gent), maar hij besluit dat de burgers uiteindelijk heel goed weten hoe ze moeten kiezen. Vervolgens bespreekt Verhulst nog een ander verwoordingprobleem, namelijk de vermenging van meerdere attitudeobjecten (ineengeschoven vraagstelling), maar ook dit wordt gerelativeerd omdat het zelden zou voorkomen en omdat het eenvoudig op te lossen is door "van staatswege op eenheid van onderwerp te toetsen", zoals gebeurt in Zwitserland. Tenslotte wordt, tegen de stelling van Magleby in, gesteld dat bij verkiezingen van partijen en kandidaten in een representatieve democratie de burgers veel meer in het duister tasten dan bij directe democratische besluitvorming. In het licht daarvan zouden alle mogelijke bezwaren tegen de vraagstelling in het niets verdwijnen. ${ }^{15}$

Wat over al deze beweringen te denken? Het zou kunnen dat het sterk beklemtonen van het probleem van de vraagverwoording ingegeven is door de ideologie van de auteurs, in dit geval een afwijzing van de directe democratie. Maar hetzelfde geldt voor degenen die dit probleem minimaliseren. Daarom is het nodig om dit aspect nuchter en zakelijk te bekijken, d.i. los van de eigen voorkeur. In 171.

${ }^{10}$ Voor een overzicht zie: I. BuDGe, The New Challenge of Democracy. Cambridge, Polity Press, 1996, 131 -

${ }^{11}$ G. De GeEST, De vraagstelling bij een referendum, in: Res Publica, 38 (1) (1986), 3-21.

${ }^{12}$ P.C. GilhuIs, Het referendum. Een rechtsvergelijkende studie. Alphen aan de Rijn, Samson, 1981.

${ }^{13}$ Zie: Een volksraadpleging met een andere vraag, in: De Gemeente, 4 (1999), 28; Van Genk tot Gent, in:De Gemeente, 4, 29-109.

${ }^{14}$ Zie hiervoor: B. Holleman, op. cit. 2000, 214-215; zie ook: Ph. VAN PRAAG, Samenvattende rapportage van de onderzoeken in het kader van de evaluatie van de referenda over Ijburg en de Noord-Zuidlijn in 1997. Amsterdam, Gemeente Amsterdam, 1997; P.C. GILHUIs, Een verankerde plaats voor het referendum in het Nederlands staatsbestel?, in R.M THEMIS, 8 (1999), 516 (met verwijzingen naar referenda in Amsterdam, Haarlem, Leiden, Woerden en Zoetemeer); J. BокмA, Wordt het ooit nog wat met het referendum?, in: Tijdschrift voor Bestuurswetenschappen en Publiekrecht, (1997), 530-533.

${ }^{15} \mathrm{~J}$. VERHULST, Het verdiepen van de democratie. Feiten, argumenten, ervaringen omtrent de invoering van het referendum. Brussel, Uitgeverij Cypres, 1998, 135-136. 
dit licht is het alvast aangewezen om het probleem van de vraagverwoording niet te reduceren tot een probleem van al dan niet manipulatie. Vraagverwoordingen die tegen een aantal regels ingaan, en die eventueel nadien als manipulatie geduid worden, hoeven niet steeds het doject van een bewuste misleiding te zijn. Onvoldoende kennis m.b.t. formuleren van vragen kan aan de basis liggen.

\section{Het beantwoorden van keuzevragen: empirische en theoretische inzichten}

De meeste studies zijn van de hand van juristen die niet zo vertrouwd zijn met het empirische onderzoek inzake vraagverwoording. Het artikel van G. De Geest uit 1986 over de vraagstelling bij een referendum in Res Publica ${ }^{16}$ is hier een typevoorbeeld van. Dit is bij mijn weten de enige Belgische studie die expliciet over de vraagstelling in het referendum handelt. De auteur baseert zich bij de bespreking van een aantal problemen van vraagstelling vooral op de rechtsvergelijkende studie van P.C. Gilhuis. ${ }^{17}$ Daarin komen verschillende bekende problemen rond de vraagstelling aan bod: het niet voorleggen van de meest kanshebbende alternatieven; het verschil in reikwijdte of scope van de keuzealternatieven; het verschil in de mate van concreetheid van de aangeboden alternatieven; het gebrek aan eenheid in de materie. Daarnaast worden op basis van een interview dat wij in 1983 hadden in een krant, ${ }^{18}$ een aantal aspecten van vraagverwoording bij opinievragen behandeld zoals het gebruik van gevoelsgeladen termen, het onevenwichtig gebruik van argumenten, de onduidelijkheid van de woorden, en zinswendingen. Men vindt er wel een verwijzing naar een aantal bekende werken ${ }^{19}$ maar gespecialiseerde literatuur, ook het Nederlands taalgebied, ontbreekt. ${ }^{20}$ De studie in Res Publica heeft als grote verdienste dat het probleem daar scherp gesteld wordt. Laten we eens kijken naar de stand van zaken m.b.t. het onderzoek en de theorievorming over het beantwoorden van keuzevragen en de verwoordingeffecten.

\section{A. Onderzoek naar effecten van de vraagverwoording bij antwoorden op opinievragen}

In het empirisch onderzoek naar effecten of zgn. meetfouten wordt een onderscheid wordt gemaakt tussen de 'ware' voorkeur (of opinie) van een subject en de geregistreerde voorkeur (of opinie) zoals deze uitgedrukt wordt door het kiezen van een antwoord op een vraagstelling. Het ene bestaat inwendig in het bewustzijn, het andere is extern waarneembaar. Het alledaagse denken gaat er doorgaans impliciet van uit dat het gekozen antwoord een zuivere meting is van de 'ware' voorkeur of opinie, maar hetgeen voorafgaat toont aan dat dit niet noodzakelijk het geval is. In de onderzoeksliteratuur over het 'meten' van opinies wordt uitgegaan van de volgende uitdrukking:

$$
\mathrm{X}=\mathrm{T}+\mathrm{I}+\mathrm{e}
$$

De geregistreerde opinie $(\mathrm{X})$ is steeds een functie van drie factoren: de ware opinie (' $\mathrm{T}$ ' van 'true') die niet bekend is en die nooit rechtstreeks wordt waargenomen, systematische meetfouten ('I' van 'inva-

\footnotetext{
${ }^{16}$ G. DE GEEST, o.c. 1986, 3-21.

${ }^{17}$ P.C. GILHUIS, Het referendum. Een rechtsvergelijkende studie. Alphen aan de Rijn, Samson, 1981.

${ }^{18}$ Dossier “Opiniepeiling: evangelie of boerenbedrog?", De Standaard, 7 november 1983.

${ }^{19}$ S. Sudman en N. BradBurn, Asking Questions. London, Jossey Bass, 1982; A. OPPENHEIM, Questionnaire design and atitude measurement. London, Heinemann, 1973; C. JAVAU, L' enquête par questionnaire. Brussel, ULB, 1978; S.L. PAYNE, The art of asking questions. Princeton, Princeton University Press, 1951.

${ }^{20}$ H. SCHUMAN en S. PRESSER, Questions and Answers in Attitude Surveys: Experiments on Question Form, Wording, and Context. New York, Academic Press, 1981. Dit was het referentiewerk in die periode en ook nu nog trouwens. N. MolEnAAR, Formuleringseffecten in survey-interviews. Doctoraatsproefschrift, Amsterdam, VU Uitgeverij, 1986; J. BILLIET, G. LOOSVELDT en L. WATERPLAS, Het survey interview onderzocht. Effecten van het ontwerp en gebruik van vragenlijsten op de kwaliteit van de antwoorden. Leuven, SOI, 1984.
} 
lidity' of ongeldigheid), en toevallige meetfouten ('e' van toevallige fouten of onbetrouwbaarheid). ${ }^{21}$ We komen op deze drie componenten verder nog terug. Zowel in de context van het sociaal wetenschappelijk onderzoek als in de context van referenda zijn we niet geïnteresseerd in individuele ware antwoorden (of scores), maar in de distributie van een voorkeur of opinie in een bevolking. Resultaten van opiniepeilingen en van referenda leveren schattingen op van deze spreiding in een welomschreven populatie.

Men neemt aan dat de voorkeur (voor een beleidsmaatregel) die iemand uitdrukt afhankelijk is van zijn of haar opinie over deze maatregel. Een opinie is immers een oordeel in termen van positief negatief, gunstig - ongunstig (of onverschillig). Om de onderlinge samenhang tussen verschillende opinies over een zelfde onderwerp, en hun (eventuele) stabiliteit, te verklaren gebruikt men het concept "attitude". Een attitude is een subjectieve toestand die eveneens niet rechtstreeks gemeten kan worden. Attitudes hebben een cognitieve, een evaluatieve (affectieve) en -gedragsdimensie (bereidheid tot handelen). Een attitude wordt volgens geëigende procedures gemeten via opinie-uitspraken m.b.t. een attitudeobject. Bij het maken van keuzen spelen vanzelfsprekend niet alleen opinies maar evenzeer de onderliggende attitudes een belangrijke rol. Om zicht te krijgen op de wijze waarop ondervraagden tot een keuze van antwoordmogelijkheden komen om hun voorkeur uit te drukken, moet men inzicht hebben in de vorming van opinies.

De bevindingen met betrekking tot de zgn. response effecten zijn overwegend afkomstig van zgn. 'split ballot' experimenten waarbij aan vergelijkbare toevalssteekproeven een zelfde vraag in verschillende varianten wordt voorgelegd. Op basis van dit onderzoek kan men analytisch een viertal response effecten onderscheiden. ${ }^{22}$ Een eerste categorie van effecten heeft te maken met de overtuigingskracht van de vraag. Men kan respondenten in een bepaalde richting sturen door argumenten in de vragen op te nemen, door gekleurde informatie in de inleiding op de vraag of door onevenwichtigheid in de vraagformulering of antwoordschaal. Een tweede categorie van effecten houdt verband met de specifieke omstandigheden en de conversatiecontext waarin de vragen worden beantwoord. De meeste ondervraagden zijn tijdens een interview of bij een schriftelijke enquête niet geneigd de spelregels te wijzigen. ${ }^{23}$ De doorsnee respondent beantwoordt iedere vraag dan binnen het aangeboden kader, ook al wordt hij daardoor in zijn antwoordmogelijkheden sterk beperkt. Een derde categorie van effecten heeft betrekking op informatie in de antwoordschalen die de ondervraagden onbedoeld gebruiken om hun antwoord samen te stellen. ${ }^{24}$ Een vierde categorie van effecten bij opinievragen heeft betrekking op het referentiekader van de ondervraagde. Hierbij speelt de context van de vraag, d.w.z. voorafgaande vragen en antwoorden, een belangrijke rol. Voorafgaande vragen en antwoorden kunnen de betekenis van een volgende vraag wijzigen of de aandacht van de respondent aanscherpen. Het antwoord op een vraag kan dan in contrast of in overeenstemming met de vorige vragen geformuleerd worden.

\section{B. Het vraag en -antwoordproces: theoretische inzichten}

In het midden van de jaren tachtig heeft het onderzoek naar de rol van de vraagverwoording en de antwoordschaal bij het uitdrukken van een keuze (opinie) een stevige stap voorwaarts gezet. Dit gbeurde door de ontmoeting van het opinieonderzoek met de bevindingen vanuit de cognitieve psycho-

${ }^{21}$ J. BILLIET, Methoden van sociaal-wetenschappelijke onderzoek: ontwerp en dataverzameling. Leuven, Acco, 1995, 88-90; R.M. Groves, Measurement Error accross the Disciplines, in P. BIEMER, et al. (Eds.), Measurement Errors in Surveys. New York, John Wiley \& Sons, 1989, 1-25.

22 J. BILLIET, o.c. 2000, 257-260.

${ }^{23}$ H. SCHUMAN en S. PRESSER, o.c. 1981, 298-299.

${ }^{24}$ N. SChwarZ, F. Strack, G. MüLlER en B. Chassein, The range of response alternatives may determine the meaning of the questions. Further evidence on informative functions of response alternatives, in: Social Cognition, 6 (1988), 2, 107-117. 
logie $^{25}$ en de linguistiek. ${ }^{26}$ Zonder al te uitvoerig in te gaan op de ontwikkelde theorie over het beantwoorden van (opinie)vragen ${ }^{27}$ moet toch even de essentie van deze 'social cognition' benadering vermeld worden. Dit moet toelaten om veel van de te verwachten effecten te begrijpen.

${ }^{25}$ J.M. Graesser en T. MurachVER, Symbolic Procedures of Question Answering, in A.C. GraESSER en J.B. Black (eds.), The Psychology of Questions. Hillsdale, Erlbaum, 1985, 15-87.

${ }^{26}$ H.P. Grice, Logic of conversation, in P. Cole en J.L. Morgan (eds.), Syntax and Semantics 3/Speech Acts. New York, Academic Press, 1975, 41-58; G. GREWENDORF, What Answers can be given?, in F. KIEFER (ed.), Questions and Answers. Dordrecht, Reidel, 1983, 45-84.

${ }^{27}$ Zie: J. BLLLET, o.c. 2000, 251-256. 


\section{Figuur I.}

Het tot stand komen van het antwoord m.b.t. een opinie

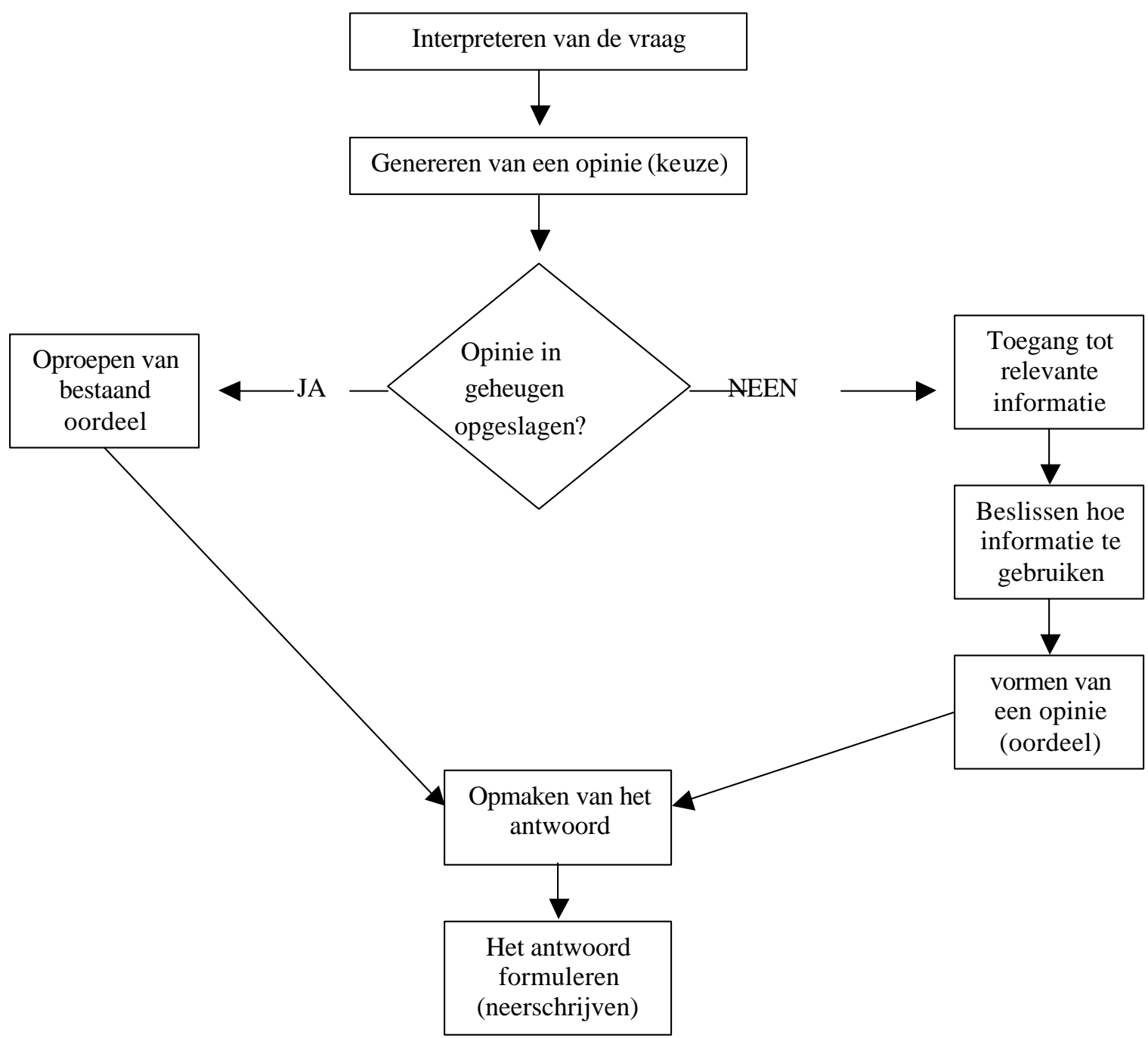

De cognitieve modellen van het vraag en -antwoordproces in opiniepeilingen zijn varianten van een basismodel waarin (1) het interpreteren (begrijpen) van de vraag, (2) het zoeken naar nuttige informatie in het lange termijn geheugen, (3) het genereren en editeren van een antwoord, en (4) het articuleren van het antwoord, de vier basisstappen zijn (zie Figuur 1). ${ }^{28}$. Er wordt op gewezen dat het opzoeken van informatie in het geheugen niet alleen een rol speelt bij vragen over feiten of gebeurtenissen maar evenzeer bij opinies en oordelen met het oog op het kiezen van alternatieven. Attitudeobjecten

${ }^{28}$ R. TOURANGEAU en K.A. RASINSKI, Cognitive processes underlying context effects in attitude measurement, in: Psychological Bulletin, 103 (1988), 299-314; F. STRACK en L. MARTin, Thinking, Judging and Communicating: A Process Account of Context Effects in Attitude Surveys, in: J.J. HIPPLER, N. SchwARZ en S. Sudman (eds.), Social Information Processing and Survey Methodology. New York, Springer Verlag, 1987, 123-148. Syntheses van de theorie en het onderzoek zijn te vinden in: N. SCHwARZ en S. SudMAN (Eds.), Answering Questions. Methodology for Determining Cognitive and Communicative Processes in Survey Research. San Francisco, Jossey-Bass Publishers, 1996; S. Sudman, N.M. BrADBURN en N. SchWARZ, Thinking about Answers. The Application of Cognitive Processes to Survey Methodology. San Francisco, Jossey-Bass Publishers, 1996; N. Schwarz en S. Sudman (Eds.), Context Effects in Social and Psychological Research. New York, Springer, 1992. 
en vroegere oordelen, gevoelens en informatie daaromtrent zijn immers eveneens in het geheugen opgeslagen in associatieve netwerken. ${ }^{29}$

Soms zal de ondervraagde, gebruikmakend van overwegingen, zich een volledig nieuw oordeel moeten vormen, maar in veel gevallen zal de herinnering aan een gevormde opinie een rol spelen bij het beantwoorden van de vraag. Dit is zeer waarschijnlijk het geval bij een referendum omdat de vragen vooraf bekend zijn, en omdat er een informatiecampagne aan vooraf gaat op grond waarvan de burger zich een oordeel zal gevormd hebben in wisselwerking met bestaande predisposities (zie verder). In dit geval gaat het natuurlijk om een verplaatsing van het moment van keuze. Ook bij de keuze in de periode voorafgaand aan de beslissende keuze op de dag van het referendum komt het antwoord mede tot stand op basis van een (gepubliceerde) vraagtekst

In elk van deze stappen kunnen externe factoren het antwoord helpen 'vormen' (of 'verstoren') zoals bijvoorbeeld de context van het vraaggesprek (o.m. hints van de interviewer), de context van voorafgaande vragen, informatie waarop recent de aandacht werd gevestigd ('priming'), en de reeds bestaande predisposities. Het is in dit kader dat de belangstelling voor het concept 'toegankelijkheid van informatie' ('information accessibility') moet begrepen worden bij het interpreteren van antwoorden op opinievragen. Daardoor kunnen een aantal response effecten verklaard worden: ondervraagden zouden de neiging hebben om zowel bij het interpreteren van de vraag als bij het maken van een keuze de gemakkelijkst bereikbare informatie te gebruiken. Dat is vanzelfsprekend informatie die recent werd gebruikt of werd opgewekt zoals informatie in de tekst van de vraag of de antwoordschaal, de antwoorden op vorige vragen, de informatie in een bijgevoegde brochure, en recente informatie in de media.

Naast de onderzoekstraditie uit de 'social cognition' benadering zijn nog een paar andere bronnen van inzicht relevant om de keuze van antwoorden op opinievragen te begrijpen. Vanzelfsprekend is de beslissingtheorie van belang. Hoe en op basis van welke overwegingen maken individuen een keuze? Hoeveel en welke informatie wordt gebruikt? Wat speelt een rol bij het afwegen van overwegingen (verwacht nut, risico of nadeel)? ${ }^{30}$ In de beslissingstheorie wordt terecht gesteld dat individuen bij het maken van een keuze vaak falen bij het beschouwen van alle mogelijke alternatieven, dat ze belangrijke gevolgen vaak over het hoofd zien, en dat zij er weinig in slagen de kansen op voor en -nadelen correct in te schatten. ${ }^{31}$ Dit inzicht is vooral van belang bij het ontwerpen van informatie brochures met het oog op de vorming van een opinie.

Specialisten in het onderzoek naar het vraag en -antwoordproces hebben er op gewezen dat alle stappen in dit proces ook geëvalueerd worden vanuit de pragmatische doelstelling van de deelnemers aan het een bevraging. ${ }^{32}$ Deze pragmatische doelen houden niet alleen verband met het reeds besproken verwachte nut, maar ook met de zelfpresentatie (sociale wenselijkheid) van de betrokkene. Impliciete conversatienormen blijken eveneens een rol spelen bij het interpreteren en beantwoorden van

${ }^{29}$ J.R. ANDERSON en G.H. BowER, Human associative memory. Washington DC, Winston en Sons, 1973; R. TourangEAu en K.A. RASinski, o.c. 1988, 2989; S. Sudman, N.M. BradBuRN en N. SchWARZ, o.c. 1996, 70-72.

${ }^{30}$ Zie hierover o.m. P. NEIJENS, The Choice Questionnaire. Design and evaluation of an instrument for collecting informed opinions of a population. Amsterdam, UvAmsterdam, 1987, 17-31; D. KAHNEMAN, P. SLOVIC, en A. TVERSKY (Eds.), Judgement under uncertainty: heuristics and biases. London, Cambridge.

${ }^{31}$ P. NEIJENS, o.c. $1987,31$.

32 J.M. Graesser en T. MurachVer, Symbolic Procedures of Question Answering, in A.C. Graesser, en J.B. BLACK (eds.), The Psychology of Questions. Hillsdale, Erlbaum, 1985, 27-28. 
vragen. ${ }^{33}$ Dit laatste is echter niet van belang voor schriftelijk gestelde referendumvragen omdat het daar niet om een conversatiecontext gaat.

Nog belangrijker voor het begrijpen van de antwoorden op opinievragen, zijn de inzichten van Zaller in "The Nature and Origins of Mass Opinion". ${ }^{44}$ Men kan er niet zomaar van uitgaan dat de respondenten een duidelijke opinie hebben over de onderwerpen die hen worden voorgelegd en dat ze die opinie ook kunnen verwoorden als antwoord op een vraagstelling. Opinies zijn geen objecten die de ondervraagden al of niet feitelijk bezitten, en waarvan zij weten of zij die bezitten. De meeste respondenten zijn ambivalent m.b.t. allerhande onderwerpen. Zij staan constant bloot aan een stroom van (politieke) informatie die hun opinie in de ene of de andere richting kan duwen. Zij zijn zich daar doorgaans niet van bewust en hun 'reservoir' wordt gevuld met allerhande inconsistente informatie waaraan ze weinig aandacht besteden. Er is echter, afhankelijk van hun betrokkenheid bij het onderwerp (het cognitief engagement) en van de dieperliggende attitude m.b.t. het onderwerp, een zekere predispositie om bepaalde informatie wél op te slaan en andere informatie niet. Deze predispositie is mede afhankelijk van de milieus (en groeperingen) waarin mensen zich bewegen en van de socialisatie tijdens de adolescentie en de periode daarna. In zijn RAS model (Receive-Accept-Sample) vat Zaller opinie-uitspraken op als de uitkomst van een proces waarin individuen nieuwe informatie ontvangen (receive), beslissen of zij deze accepteren en vervolgens een selectie maken (sample) op het moment dat zij een opinievraag beantwoorden. De vier axioma's ${ }^{35}$ waarop dit model is gestoeld, - receptie van informatie, weerstand tegen informatie, toegankelijkheid van informatie, selectie van informatie, - zijn van groot belang om de antwoorden op keuzevragen te begrijpen.

Dit RAS model kan een verklaring verschaffen voor het gebrek aan stabiliteit van de antwoorden op opinievragen. De informatie die in overweging wordt genomen bij het beantwoorden van de vragen kan immers verschillend zijn naargelang van de context. Het model verklaart ook waarom, in geval van ongewijzigde opinies, de antwoorden stabieler zijn bij degenen die meer uitgekristalliseerde of sterke opinies hebben (predispositie, receptie). Zij gaan bewuster om met de informatie die op hen afkomt. Het RAS model bevat eveneens een aanzet voor het beantwoorden van de complexe vraag onder welke omstandigheden de kans toeneemt dat opinies werkelijk veranderen. ${ }^{36}$

We zullen de in het onderzoek gevonden response effecten nu rechtstreeks toepassen op referenda en volksraadplegingen en vervolgens de vraag beantwoorden hoe ernstig zulke vertekeningen kunnen zijn.

\section{Response effecten bij keuzevragen in referenda en volksraadplegingen}

De vragen in een referendum of volksraadpleging zijn keuzevragen met een beperkt aantal antwoordmogelijkheden ${ }^{37}$ Bovendien gaat het om gesloten keuzevragen. Daarover bestaat algemene eensgezindheid. Dit wil zeggen dat de ondervraagde slechts de mogelijkheid heeft om uit die aangeboden alternatieven te kiezen, of geen van alle te kiezen. De ondervraagde kan zelf geen nieuwe antwoordmogelijkheden toevoegen.

${ }^{33}$ H.P. Grice, Logic of conversation, in P. ColE en J.L. Morgan (eds.), Syntax and Semantics 3/Speech Acts. New York, Academic Press, 1975, 41-58; G. GREWENDORF, What Answers can be given?, in F. KIEFER (ed.), Questions and Answers. Dordrecht, Reidel, 1983, 45-84. Voor een verder uitwerking en voorbeelden i.v.m. het interview zie: J. BILLIET, o.c. 2000, 265.

${ }^{34}$ J.R. ZALLER, The nature and origins of mass opinion. Cambridge, Cambridge University Press, 1992.

${ }^{35}$ Ibid. 43-51.

${ }^{36}$ Voor een toepassing in de context van referenda zie: H.P. KRIESI en D. BÜTSCHI, Opinion formation and change. The case of the Swiss policy against air pollution caused by cars. Department of Political Science, University of Geneva (onderzoeksrapport), 1999.

${ }^{37}$ Zie: P. NeIJENS, The Choice Questionnaire. Design and evaluation of an instrument for collecting informed opinions of a population. Amsterdam, UvAmsterdam, 1987, 17-31. 
Een eerste vorm van manipulatie die gesignaleerd wordt, is het niet voorleggen van die alternatieven die een reëel maatschappelijk draagvlak hebben. ${ }^{38}$ Men laat in dit geval aan de bevolking de keuze tussen de alternatieven $\mathrm{A}$ en $\mathrm{B}$, terwijl de meerderheid in feite voor alternatief $\mathrm{C}$ is. Zoals reeds vermeld, werd in een reeks onderzoeken aangetoond dat een aanzienlijk deel van de ondervraagden toch een keuze maakt uit de antwoordmogelijkheden, ook indien de antwoordmogelijkheden die eigelijk bij hen passen, ontbreken. ${ }^{39}$ Dit onderzoek heeft betrekking op opiniepeilingen en dat is niet hetzelfde als een volksraadpleging waaraan beleidsconsequenties verbonden zijn als gevolg van de keuze. Het is dus niet geweten of in de context van volksraadplegingen de ondervraagden minder gevoelig zijn voor deze vorm van manipulatie en bijgevolg vlugger geneigd zijn om niet te kiezen indien de aangeboden keuzemogelijkheden niet adequaat zijn. De inzichten uit de cognitieve psychologie over het beantwoorden van vragen doen echter sterk vermoeden dat deze beperking vanwege de aangeboden alternatieven eveneens van toepassing is bij volksraadplegingen. Vanzelfsprekend kan met nooit alle mogelijke alternatieven voorleggen in een referendumvraag, al was het maar dat de antwoordverdeling dan niet meer te interpreteren is in termen van meerderheid of minderheid (zie verder). Men zou in de regel echter die alternatieven moeten aanbieden waarover in de bevolking een debat wordt gevoerd (alternatieven die leven in de publieke opinie) en waarrond zich opinies uitkristalliseren.

Een tweede probleem heeft te maken met het ondubbelzinnig bepalen van de meerderheid. In het geval van twee substantiële antwoordmogelijkheden (ja/neen, eens/oneens) daarnaast toch nog de mogelijkheid van "geen opinie" bestaat, zal het percentage dat het met een maatregel eens of oneens is aanzienlijk verschillen naargelang men bij de berekening de onbesliste deelnemers ${ }^{40}$ wel of niet in rekening neemt. Indien tussen méér dan twee antwoordalternatieven kan worden gekozen, dan neemt de dubbelzinnigheid met een veelvoud toe. Dit werd overtuigend aangetoond in het werk van Budge $(1996)^{41}$ Condorcet heeft reeds in 1785 dit probleem in mathematische termen uitgewerkt. ${ }^{42}$ Vereenvoudigd gesteld heeft men de keuze tussen drie berekeningswijzen die elk hun voor en -nadelen hebben. Ofwel neemt men als meerderheid het alternatief dat het meest aantal keren als eerste werd aangeduid. Ofwel haalt men uit de individuele antwoorden alle geordende paren en neemt men als meerderheid het alternatief dat het meest aantal keren eerst voorop staat. Ofwel kent men scores toe aan de alternatieven naargelang van de rangorde ${ }^{43}$ en wordt de meerderheid bepaald aan de hand van de somscores (het alternatief met de hoogste somscore, d.i. de zgn. Borda ${ }^{44}$ telling). De vele problemen en

${ }^{38}$ G. DE GEEST, De vraagstelling bij een referendum, in: Res Publica, 38 (1) (1986), 4-5; P.C. GILHUIS, Het referendum. Een rechtsvergelijkende studie. Alphen aan de Rijn, Samson, 1981, 179-180.

${ }^{39}$ J. BILLIET, Opiniepeiling of manipulatie van de publieke opinie?, in: Intermediair, 2, 20 jan. (1984), 3-7; J. BILLIET, G. LOOSVELDT en L. WATERPLAS, Het survey interview onderzocht. Effecten van het ontwerp en gebruik van vragenlijsten op de kwaliteit van de antwoorden. Leuven, SOI, 1984; J. BILLIET, G. LOOSVELDT en L. WATERPLAS, Response-effecten bij survey vragen in het Nederlands taalgebied. Leuven, SOI, 1988; J. BILLIET, Research on Question Wording Effects in Survey Interviews, in: Graduate management Research, 5 (1991), 4, 66-80; H. SCHUMAN en S. PRESSER, o.c. 1981, 298-299.

${ }^{40}$ We verkiezen de term 'deelnemers' boven 'kiezers'.

${ }^{41}$ Zie hiervoor: I. BuDGE, The new challenge of direct democracy. Cambridge US, Blackwell Pub., 1996, 161-162.

${ }^{42}$ Marquis de CONDORCET, Essai sur l'application de L'Analyse a la Probabilité des décisions rendues à la pluralité des voix. Paris, Imprimerie Royale, 1785.

${ }^{43}$ De eerste vraag in de Copernicus bevraging (hoe met de overheid communiceren) is hier een voorbeeld van maar de vraag was niet correct geformuleerd omdat hier geen sprake was van rangschikken maar het toekennen van punten, waarbij aan de meeste punten de laagste score diende toegekend te worden. De kwestie die we hier bespreken heeft echter niet te maken met de verwarring bij de vraagstelling maar met de moeilijkheid van het verwerken van de antwoorden om de rangorde van de voorkeur in de totale verzameling van deelnemers ondubbelzinnig vast te stellen

${ }^{44}$ Zie: J.D. DE BORDA, Mémoire sour les Elections au Scrutin, in:Mémoires de l'Académie Royale des Sciences Année 1781. Paris: Académie des Sciences, (1784), 95-110. 
mogelijkheden van manipulatie zijn voldoende gedocumenteerd in de literatuur ter zake. ${ }^{45}$ Samengevat is het duidelijk dat de wijze van het toekennen en de verwerking van numerieke scores, zowel rechtstreeks als na een sorteringstaak, tot zeer verschillende beslissingen kan leiden m.b.t. de vaststelling van de "meerderheid" voor een alternatief onder de deelnemers. Soms kan de meerderheid niet eens vastgesteld worden en in andere gevallen is de meerderheid betwistbaar naargelang van het criterium dat men hanteert ${ }^{46}$ Het besluit hieruit is duidelijk: bij referenda is het niet aangewezen om meerkeuzevragen te gebruiken omdat het dwingend karakter ervan vereist dat de meerderheid ondubbelzinnig kan vastgesteld worden. In het geval van volksraadplegingen die richtinggevend zijn, zou dit mits de nodige reserve wel mogelijk zijn. De wijze van tellen zou dan vooraf moeten vast liggen en meegedeeld worden.

Meestal worden in referenda de twee bovenvermelde moeilijkheden vermeden door slechts één alternatief voor te leggen waarbij de referendumvraag de vorm heeft van een "ja" of "neen" ("voor" of "tegen") vraag. ${ }^{47}$ Doch ook deze vraagvorm is niet gevrijwaard van verwarring of manipulatie. Zo vindt men in het standaardwerk van Butler en Ranney (1994) ${ }^{48}$ de verwijzing naar verschillende Amerikaanse studies waarin wordt gesteld dat de vragen vaak zo verwoord zijn dat een "Ja" stem in feite een stem tegen een specifieke beleidsmaatregel is. Indien men dus voor het invoeren van de maatregel is zou men dus "neen" moeten stemmen. Wij kunnen hier nogmaals wijzen op de bekende studie van Magleby $^{49}$ waarin melding gemaakt wordt van 10 tot 20 procent "foute" antwoorden (d.i. burgers die voor de maatregel zijn stemmen "Ja" in plaats van "Neen") als gevolg van deze praktijk. ${ }^{50} \mathrm{Z}$ ulke vragen zijn tevens verwarrend omwille van de zgn. "dubbele negatie".

Met betrekking tot "ja/neen" vragen duikt in de literatuur nog een ander probleem op. De burger die zich uitspreekt weet precies wat hij of zij afwijst indien de keuze "neen" is, maar het is onduidelijk wat een "ja" inhoudt omdat dan impliciet tal van mogelijkheden open blijven. ${ }^{51}$. Neem bijvoorbeeld de vraag die door de Gentse gemeenteraad werd opgesteld na een negatief advies over een vorige verwoording van de adviescommissie: "Moet het stadsbestuur in overleg met De Lijn en het Vlaams Ge-

\footnotetext{
${ }^{45}$ Voor een overzicht zie: I. BUDGE, o.c. 1996, 135-159.

${ }^{46}$ Wij hebben niet de indruk dat deze materie tot op heden grondig werd overwogen bij de organisatie van zgn. volksraadplegingen. Opnieuw is de zgn. Copernicus-bevraging een type voorbeeld van hoe het best niet moet.

${ }^{47}$ Wat de gemeentelijke en provinciale volksraadplegingen in België aangaat, wordt uitdrukkelijk gesteld dat het om vragen van het "ja/neen” type moet gaan. Zie hier voor de verwijzingen in voetnoot nr. 99.

${ }^{48}$ D. BUTLER en A. RANNEY, Referenda around the World. The growing use of direct democracy. London, MacMillan, 1994, 18.

${ }^{49}$ D. Magleby, Direct Legislation: Voting on Ballot Propositions in the United States. Baltimore, John Hopkins University Press, 1984.

${ }^{50}$ De vraag die op 14 december 1997 tijdens het eerste referendum over een ondergrondse parking aan de inwoners van Gent werd voorgelegd is hier een voorbeeld van: "Moet de beslissing van de gemeenteraad om de ondergrondse Belfortparking te bouwen herroepen worden? Ja of neen?" (De Gemeente, 4, 1999,91). Wie voor de beslissing is om de parking te bouwen zegt hier "neen". Bemerk dat de term "herroepen" waarschijnlijk niet door iedereen begrepen wordt. Er zit ook een dubbele negatie in de vraag. Zie: Vlaams Parlement. Stuk 1115 (1997-1998) - Nr. 1, p. 5 en 12. De gevolgen voor het foutief stemmen zouden nochtans volgens de exit-poll van de VUB niet zo dramatisch zijn. De onderzoekers ramen globaal het aantal foutieve antwoorden op 1,3\%. Toch zou bij de minderheid van de voorstanders zich 17\% vergist hebben. Maar dat zou mede het gevolg zijn van het gebrek aan informatie onder de voorstanders waarvoor geen campagne werd gevoerd omwille van de aanbeveling niet deel te nemen. Zie: Vlaams Parlement. Stuk 1115 (1997-1998) - Nr. 1, p. 6.

${ }^{51}$ Neem bijvoorbeeld de vraag die door de Gentse gemeenteraad werd opgesteld na een negatief advies over een vorige verwoording van de adviescommissie: "Moet het stadsbestuur in overleg met De Lijn en het Vlaams Gewest binnen het jaar een openbaar vervoersplan opmaken en vervolgens uitvoeren om het aantal gebruikers van het openbaar vervoer in Gent op tien jaar te verdubbelen". Het is onduidelijk voor wat de burger precies kiest indien "ja" de meerderheid zou halen. Hier moet de burger uitspraak doen over een (nobele) bedoeling zonder echt te weten wat het plan precies zal inhouden
} 
west binnen het jaar een openbaar vervoersplan opmaken en vervolgens uitvoeren om het aantal gebruikers van het openbaar vervoer in Gent op tien jaar te verdubbelen". Het is onduidelijk voor wat de burger precies kiest indien "ja" de meerderheid zou halen. De overheid krijgt hier m.a.w. een door een volksraadpleging gelegitimeerde blanco cheque die een ganse gamma van alternatieven $(A, B, \ldots$, N) zou kunnen inhouden om een verre doelstelling te realiseren. ${ }^{52}$ De praktijk om te laten stemmen over principes in plaats van uitgewerkte voorstellen komt steeds neer op een keuze voor een gamma van alternatieven. Hier moet de burger uitspraak doen over een (nobele) bedoeling zonder echt te weten wat het plan precies zal inhouden. De keuze tussen algemene principes dan wel concrete voorstellen heeft als zodanig niets met effecten van vraagverwoording te maken, maar in beide gevallen kunnen zulke effecten wel optreden door ofwel het gebruik van suggestieve woorden in het geval van principes, of door het aanbieden van niet reële alternatieven in het geval van concrete voorstellen.

Een grondig onderzochte moeilijkheid bij het gebruik van "ja/neen" vragen is complexer en we zullen ons hier beperkten tot de essentie. In een recent doctoraatsproefschrift heeft Holleman $(2000)^{53}$ gebruik makend van de inzichten uit de cognitieve psychologie het antwoorden op "ja/neen" vragen onderzocht aan de hand van de zgn. "verbieden/toelaten" asymmetrie. ${ }^{54}$ Deze asymmetrie bestaat er in dat zowel in panel onderzoek (meermaals ondervragen van dezelfde respondenten) als in gesplitste vergelijkbare toevalssteekproeven er systematisch en significant méér respondenten zijn die een maatregel niet toelaten (toelaten: neen) dan ze deze zouden verbieden (verbieden: ja). Als verklaring wordt doorgaans opgevoerd dat "verbieden: ja" veel extremer is dan "toelaten: neen" omwille van de woordtonaliteit. Via experimenteel onderzoek komt Holleman echter tot een meer algemene verklaring die van groot belang is om de antwoorden op "ja/neen" vragen in het algemeen te begrijpen. De "verbieden" en "toelaten" vragen meten wel degelijk dezelfde attitude, m.a.w. de respondenten halen dezelfde informatie op in het geheugen, maar sommigen drukken hun antwoorden anders uit op de antwooordschalen ("ja/neen"). Dit komt omdat, in tegenstelling met wat het lijkt, een "ja/neen" antwoordschaal geen dichotome nominale schaal is maar een glijdende schaal voor of tegen een attitudeobject (bijvoorbeeld abortus). De ligging van "ja" en "neen" op die psychologische schaal verschilt door het gebruik van "verbieden" dan wel "toelaten", of meer algemeen, naargelang van de aangeboden werkwoorden in de vraagstelling. (beperken/vrij laten, goedkeuren/afkeuren, stoppen/verder zetten, handhaven/vernietigen, behouden/intrekken, behouden/herroepen, etc...). Naargelang van de betekenis die de ondervraagde daaraan hecht in termen van extremiteit, zal de antwoordverdeling substantieel kunnen verschillen. We komen verder nog terug op een toepassing hiervan binnen een correctief referendum. ${ }^{55}$

Een zesde, en betere bekend probleem bij de vraagstelling, is het opnemen van meerdere attitudeobjecten in één vraag. Dit probleem is niet typisch voor keuzevragen maar voor alle opinievragen in het algemeen, maar het stelt zich och in het bijzonder voor keuzevragen omdat de keuze in een bepaalde richting gestuurd wordt. In de vakliteratuur spreekt men over "double barreled questions" die tot elke prijs vermeden zouden moeten worden. ${ }^{56}$ In de literatuur over referenda heeft met het over "de eenheid van onderwerp". De reden van de afwijzing van meerdere onderwerpen in één vraag is eenvou-

${ }^{52}$ G. DE GEEST, o.c. $1986,6$.

${ }^{53}$ B. HollEmAn, The forbid/allow asymmetry. On the cognitive mechanism underlying wording effects in surveys. Utrecht Studies in language and Communication, Amsterdam, Atlanta, 2000.

${ }^{54}$ Zie hiervoor: H.J. HIPPLER en N. SCHWARZ, Not forbidding isn't allowing: the cognitieve basis of the forbid/allow assymetry, in: Public Opinion Quarterly, 50 (1986), 97-96; L. WATERPLAS, J. BILLIET en G. LOOSVELDT, De verbieden versus niet toelaten asymmetry. Een stabiel formuleringseffect in surveyonderzoek?, in: Mens en Maatschappij, 63 (1988), 399-415.

${ }^{55}$ Holleman paste haar bevinding toe op een correctief referendum dat in Amsterdam werd gehouden met betrekking tot een gemeentelijk besluit inzake een tramtracé (zie IV.A. van deze studie).

${ }^{56}$ A.N. OPPENHEIM, Questionnaire design and attitude measurement. London, Heinemann, 1966, 56-57, 1115. 
dig. Bij de keuze voor een "ja" antwoord weet men niet voor welk van de twee (of meer) objecten de ondervraagde kiest. Dat is precies de reden waarom zulke dubbelzinnigheid gebruikt wordt. Men plaatst een zeer aanvaardbare maatregel als aandachtstrekker bij een minder aantrekkelijke die men op het oog heeft, met als bedoeling dat deze laatste door een groter aantal ondervraagden wordt gekozen. De ondervraagde is immers niet in de mogelijkheid om "ja" tegen het ene en "neen" tegen het andere omdat de keuze onverdeeld op de volledige vraagtekst betrekking heeft. Ondanks het gegeven dat het hieromtrent één van de meest onbetwistbare regels bestaat ("slechts één onderwerp per vraag"), wordt daar vaak tegen gezondigd. ${ }^{57}$ Het werk van Gilhuis bevat een aantal voorbeelden van vragen met meervoudige onderwerpen in referendums. ${ }^{58}$ Uitzonderlijk zou men kunnen instemmen met meerdere onderwerpen in geval deze inherent samen horen en een eenheid van materie vormen. Dat is trouwens een regel die in Zwitserland geldt. ${ }^{59}$ Volgens sommigen is van eenheid van materie sprake indien het gaat om twee of meer middelen gericht op het bereiken van éénzelfde doel. Anderen manen tot een grote voorzichtigheid aan en spreken van eenheid van materie indien het gaat over één middel gericht op één doel. ${ }^{60}$ Er zou eveneens van eenheid van materie sprake zijn indien de politieke coherentie het wenselijk maakt dat twee voorstellen samen worden aangenomen. ${ }^{61}$

Over de beïnvloeding van de ondervraagde door het gebruik van suggestieve woorden in de vraagstekst en de antwoordalternatieven, bestaat een zeer uitgebreide onderzoeksliteratuur. Wij zullen ons beperken tot de hoofdlijnen en tot die aspecten die mogelijks van belang kunnen zijn bij volksraadplegingen of referenda voor zover deze nog niet vermeld werden. Men kan door overtuigingskracht in de vraagstelling de deelnemers aan een raadpleging in een bepaalde richting sturen. Dit gebeurt door argumenten in de vragen op te nemen, door gekleurde informatie in de inleiding op de vraag of door onevenwichtigheid in de vraagformulering of in de antwoordschaal. In het geval van meerkeuzevragen kan men bovendien impliciet informatie in de antwoordschalen opnemen waardoor het antwoord van de ondervraagde in een bepaalde richting gestuurd wordt. Dergelijke manipulaties kunnen gemakkelijk verschillen van méér dan tien procentpunten in de antwoordverdelingen teweegbrengen. Er zijn gevallen bekend waarbij een meerheid een minderheid wordt, en omgekeerd. ${ }^{62}$

${ }^{57}$ Laten we echter een meer recent voorbeeld geven van zo'n vraag in de raadpleging over het Copernicusplan: "De overheid wil de meest bekwame medewerkers aantrekken voor deze topfuncties en moet deze topfuncties openstellen voor kandidaten van binnen en buiten de administratie" (de antwoordmogelijkheden: helemaal akkoord, akkoord, geen mening, niet akkoord, helemaal niet akkoord). Het gaat hier om twee verschillende uitspraken waarmee de ondervraagde al of niet akkoord kan gaan: (A) aanwerven van de meest bekwame medewerkers; (B) aanwerven van kandidaten van binnen en buiten de administratie. Men kan zich moeilijk voorstellen dat iemand niet akkoord zou gaan met A, en bijgevolg is het effect van deze verwoording voorspelbaar: het aantal antwoorden "(helemaal) akkoord" wordt opgedreven. Dit voorbeeld maakt echter ook duidelijk dat het niet steeds eenvoudig is om na te gaan of er wel twee of meer onderwerpen zijn. Laten we de vraag even aanpassen in een vorm die op het eerste zicht correct is: "De overheid wil deze topfuncties openstellen voor de meest bekwame kandidaten van binnen en van buiten de administratie". Hier is inderdaad slechts sprake van één attitudeobject, maar door het gebruik van een adjectief "meest bekwame" worden de antwoorden evenzeer in de gewenste richting geduwd.

${ }^{58}$ P.C. GILHUIS, o.c. 1981, 274-275.

${ }^{59}$ Zie hiervoor: G. DEGEEST, o.c. $1986,10$.

${ }^{60}$ Ibid., 10 (zie voetnoot 20).

${ }^{61}$ In de studie van De Geest worden op een formele wijze de voorwaarden gesteld om in dit geval aan het criterium "eenheid van materie" te voldoen. Neem twee voorstellen A en B, ieder met de antwoordalternatieven "akkoord" (A1 en B1) en "niet akkoord" (A2 en B2). Er is sprake van eenheid van materie indien A1 en B2 in de praktijk niet mogelijk zijn of indien de keuze tussen B1 en B2 bij een doorslaggevend aantal deelnemers afhankelijk is van de uitslag m.b.t. A1 en A2. Voor verdere uitleg van dit eerder complex vraagstuk verwijzen we naar De Geest (1986), o.c. 11.

${ }^{62}$ Zie bijvoorbeeld: J. BILLIET, Opiniepeiling of manipulatie van de publieke opinie?, in: Intermediair, 2,20 jan. 1984, 3-7. 
Het referentiekader dat de deelnemer gebruikt is van groot belang van het beantwoorden van een keuzevraag. In de recente literatuur wordt er op gewezen dat de keuze zal afhangen van de overwegingen die de ondervraagde in gedachten heeft op het moment van de keuze. Dat is trouwens een reden waarom opinies (keuzen) zo vaak wijzigen indien men kort na elkaar meerdere peilingen houdt. ${ }^{63}$ Deze overwegingen worden niet alleen levendig gemaakt door en informatiecampagne in de media, maar ook door de context van de vraag, d.w.z. voorafgaande vragen en antwoorden. ${ }^{64}$ Voorafgaande vragen en antwoorden kunnen de betekenis van een volgende vraag wijzigen of de aandacht van de respondent aanscherpen. Het antwoord op een vraag kan dan in contrast of in overeenstemming met de vorige vragen geformuleerd worden. Dit effect op de antwoorden kan in volksraadplegingen vooral optreden indien meerdere vragen samen voorgelegd worden. Maar ook in de inleiding op de vraag kunnen sturende elementen aanwezig zijn. ${ }^{65}$

Naast deze invloeden vanuit de vraagstelling op de keuze van de antwoorden, is ook sprake van zgn. response sets (of stijlen) Een response set wordt omschreven als om het even welke geneigdheid van een persoon om systematisch op een andere manier op vragen te antwoorden dan hij of zij zou doen wanneer dezelfde inhoud zou aangeboden worden in een andere vorm. ${ }^{66}$ De bekende response sets zijn: de tendens om het overal mee eens te zijn (de zgn. "ja-zeggers" of instemmingtendens, ${ }^{67}$ de tendens om sociaal wenselijk te antwoorden, om het antwoord af te stemmen op een geïnternaliseerde sociale norm, of om een goede indruk te geven aan de interviewer; de neiging om steeds dezelfde keuze te maken bij het beantwoorden van sets van uitspraken of vragen (bijvoorbeeld steeds het middenalternatief of de extremen kiezen, de keuze te maken bovenaan of onderaan een lijst) ${ }^{68}$ Het eerste, de tendens tot instemming, komt voor indien de vraag van die vorm is dat zij een "eens", "akkoord" of "ja" onder de antwoordalternatieven heeft, en daarom lijkt deze stijl niet uit te sluiten bij de keuzevragen in volksraadplegingen of referendums. Als dit verschijnsel zou voorkomen bij volksraadplegingen, iets waaraan wijzelf niet twijfelen, dan is het effect er van in elk geval beperkt. Onderzoek wijst immers uit dat in Westerse culturen het aantal respondenten dat de neiging tot instemmen vertoont tussen $5 \%$ tot $10 \%$ kan geschat worden, maar het is wel zo dat dit meer voor komt bij ouderen en lager geschoolden. ${ }^{69}$

\section{Hoe ernstig zijn verwoordingeffecten bij referenda en volksraadplegingen?}

Verscheidene van de bovenvermelde effecten van de vraagstelling werden vastgesteld in referenda en volksraadplegingen. Andere effecten werden daar nog niet vastgesteld aangezien referenda geen voorwerp zijn van experimenteel onderzoek. Ze werden wel gevonden in opiniepeilingen, zowel bij

${ }^{63}$ Zie: J.R. ZALLER, The nature and origins of mass opinion. Cambridge, Cambridge University Press, 1992.

${ }^{64}$ Zie hiervoor: N. Schwarz en S. Sudman (Eds.), Context Effects in Social and Psychological Research. New York, Springer, 1992.

${ }^{65}$ Zie: J. BLLLET, o.c. 2000, 256-263.

${ }^{66}$ L.J. CRONBACH, Response sets and test validity, in: Educational and Psychological Measurements, 6 (1946), 475-494.

${ }^{67}$ Zie o.m.: L.J. CRONBACH, Studies of acquiescence as a factor in the true-false test, in: Journal of Educational Psychology, 33 (1942), 401-415; J. MARTIN, Acquiescence: measurement and theory, in:British Journal of Social and Clinical Psychology, 3 (1964), 316-225. Meer recent: H. HERK, Equivalence in a cross-cultural context: Methodological en empirical issues in marketing research ( $\mathrm{PhD}$ thesis). Tilburg, Tilburg university, 2000.

${ }^{68}$ L.J. CRONBACH, o.c. 1946, 475-494; L.J. CRONBACH, Further evidence on response sets and test design. Educational and Psychological Measurement, 10 (1950), 3-31. Wat het kiezen bovenaan of onderaan een lijst aangaat, werd deze antwoordset gesignaleerd met betrekking tot het elektronisch stemmen (De Morgen, 20 mei 2000: verslag van onderzoek verricht aan VUB).

${ }^{69}$ Zie hiervoor: J. BLLLIET en J. MCKeE MCClendon, Modeling acquiescence in maesurement models for two balanced sets of items, in:Structural Equation Modeling. An Interdisciplinary Journal, 7(2000), 4,608-629. 
expliciet opgezette experimenten als bij volstrekt vergelijkbare peilingen in de algemene bevolking. ${ }^{70}$. Spelen deze effecten ook een rol bij referenda en volksraadplegingen, en zo ja, wat is het belang er van? Is de omvang van die aard dat ze de uitslag grondig kunnen vertekenen? Om die vragen te beantwoorden moeten we nagaan in hoever een referendum of een volksraadpleging met een opiniepeiling kan vergeleken worden.

\section{A. Verschillen referenda of volksraadplegingen van opiniepeilingen en verkiezingen?}

Voortgaande op de onderzoeksliteratuur over effecten van de vraagverwoording kan men redelijkerwijze aannemen dat zulke effecten groter zijn bij peilingen omdat de ondervraagden daar weinig bij het onderwerp betrokken zijn, over weinig informatie beschikken en soms geen uitgesproken mening hebben. Uit onderzoek is geweten dat ondervraagden die een zwakke attitude hebben met betrekking tot een onderwerp (er weinig bij betrokken zijn) vaker onbetrouwbare antwoorden geven. ${ }^{71}$ In dezelfde lijn wordt gevonden dat hoger opgeleiden meer betrouwbare antwoorden geven en minder gevoelig zijn voor response effecten, omdat hun interesse rond allerhande politieke onderwerpen doorgaans groter is. De mate waarin ondervraagden bij een onderwerp betrokken zijn (sterke attitude) bepaalt sterk het zoeken naar nieuwe informatie over het onderwerp. ${ }^{72}$ Er werd ook gevonden dat de effecten van de vraagverwoording groter zijn naarmate het bevraagde onderwerp complexer is. ${ }^{73}$

In de wetenschappelijke literatuur over referenda wordt beweerd dat, in vergelijking met de verkiezing van kandidaten bij verkiezingen, de deelnemers in een referendum beter geïnformeerd en meer gesofisticeerd zijn. ${ }^{74}$ Natuurlijk moet hier onmiddellijk bij gezegd worden dat dit niet alleen omwille van de informatiecampagne is, maar ook omdat de uitval van lager geschoolden bij referendums doorgaans nog groter is dan bij kandidaat-verkiezingen. Wie weinig op de hoogte is of wie geen uitgesproken opinie heeft, haakt vlugger af. ${ }^{75}$

Onderzoek met behulp van opiniepeilingen toont ook aan dat de deelnemers bij een referendum tijdens de campagne veel meer van opinie veranderen dan bij verkiezingen voor kandidaten. ${ }^{76}$ Uit een

\footnotetext{
${ }^{70}$ Zo stelt men bijvoorbeeld in twee peilingen door hetzelfde bureau in Vlaanderen in 1999 een verschil van gemiddeld vijftien procentpunten vast op een aantal uitspraken over het vertrouwen in het parlement, het gerecht, de administratie en de politie. Het verschil is toe te schrijven aan een verschil in de antwoordschaal, namelijk de al of niet aanwezigheid van een neutraal middenalternatief in de antwoordschaal. Zo heeft in de ene peiling $17,3 \%$ van de ondervraagden zeer veel of veel vertrouwen in het parlement; in de andere studie is dat $30,5 \%$. Zie: VRIND, Vlaamse Regionale Indicatoren. Brussel, APS, 1999, 20; K. DOBBELAERE, e.a. Inleiding. Een Project, waarden en waarderingen, in K. Dobbelaere, M. Elchardus, J. Kerkhofs, L. Voyé en B. BAwinLGROS (Eds.), De verloren zekerheid. De Belgen en hun waarden, overtuigingen en houdingen. Tielt, Lannoo, 2000,12 .

${ }^{71}$ Zie hiervoor o.m.: J. BILLIET, H. WAEGE en M. SwYNGEDOUw, Attitude strength and response stability of a quasi-balanced political alienation scale in a panel study, 1997. Paper presented at the expert Conference 'No opinion, instability and change in public opinion research'. Amsterdam, October 6-8, $20 \mathrm{pp}$. (accepted for publication in a book on No-opinion and response stability, edited by W. Saris en P. Neijens); John CURTISE, Why methodology matters, in Bridget TAYLOR en Katarina THOMsOn (Eds.), Understanding Change in Social Attitudes. Aldershot, Dartmouth Pub. Co., 1996, 131-149; G. Evans en A. HEATH, The measurement of left-right and libertarian-authoritarian values: a comparison of balanced and unbalanced scales, in: Quality and Quantity, 29 (1995), 191-206.

${ }^{72}$ P. KRIESI en D. BÜTSCHI, o.c. 1999, 285; B. MADDENS en W. DeWACHTER, Politieke belangstelling, kennis en onderlegdheid in M. Swyngedouw, J. BiLliet, A. CARTON en R. BEERTEN (red.), De (on)redelijke kiezer. Leuven, Acco, 1988, 139-158.

${ }^{73}$ B. Holleman, o.c. 131-132.

${ }^{74}$ D.B. Magleby, o.c. 1984, 141-144; Th. CROnin, Direct Democracy: The Politics of Initiative, Referendum, and Recall. Cambridge Mass, Harvard University Press, 1989, 70-77.

75 D. Butler en A. RanNey, o.c. 1994, 16-17; D.B. Magleby, Direct Legislation in the American States. 218-257 in: D. BuTLER en L. RANNEY (eds.), o.c. 1994, 242-252.

${ }^{76}$ D.B. MAGLEBY, o.c. $1994,249-250$.
} 
zeer grondig onderzoek naar de opinie t.o.v. maatregelen m.b.t. het milieu in Zwitserland, blijken deze opinieveranderingen samen te gaan met enerzijds de sterkte van de opinie (sterke mate van betrokkenheid bij het onderwerp) en van de positie die oorspronkelijk werd ingenomen (voor of -tegenstander). ${ }^{77}$ Er werd ook gevonden dat de campagnes tijdens een referendum niet alleen bijdragen tot het uitklaren van de opinie bij degenen die bij het onderwerp betrokken zijn; zij leiden ook tot een vermindering van het aantal burgers zonder opinie. Omgekeerd kunnen campagnes bij degenen die reeds een zwakke opinie hebben (weinig bij het onderwerp betrokken) de onzekerheid nog doen toenemen. ${ }^{78}$

Naast het argument dat de burgers de kans krijgen om goed geïnformeerd te worden via de campagne wordt echter ook aangevoerd dat de deelnemers aan een volksraadpleging een cognitieve handicap hebben die ze bij de verkiezingen voor kandidaten niet hebben. Bij de verkiezing van vertegenwoordigers staat het label van de partij boven aan een lijst. Dit is een cognitief hulpmiddel bij het bepalen van de keuze omdat via dit label een associatie een (eventuele) verbondenheid met een politieke familie tot stand komt. ${ }^{79}$ Daardoor is de keuze van de kiezer gemakkelijker in de mate dat hij of zij zich met een partij associeert. Ook gaat een zeker appél uit van herkenbare (politieke) figuren, iets wat geheel ontbreekt in een referendum. ${ }^{80}$ Het kan zijn dat groeperingen en politieke partijen t.o.v. de referendumvraag een standpunt hebben ingenomen, maar nergens is deze associatie aanwezig op het kiesformulier. De taak bij een volksraadpleging of referendum zou dus cognitief veel complexer zijn dan bij de verkiezing van vertegenwoordigers. Omwille van de besproken relatie tussen cognitieve complexiteit en het optreden van response effecten, zou men bijgevolg mogen verwachten dat alle vermelde effecten van de vraagstelling ook in referenda en volksraadplegingen optreden.

Voorstanders van directe democratie keren zich tegen het argument van de cognitieve complexiteit als dit impliciet als bedoeling zou hebben om te suggereren dat de burgers onbekwaam zijn voor volksraadplegingen. Bekeken vanuit het oogpunt van "onbekwaamheid" stellen zij dat dit veel meer geldt voor de verkiezing van vertegenwoordigers dan voor het kiezen van voorstellen bij een referendum. Het kiezen van kandidaten zou moeilijker zijn omdat de kiezer zich dan een oordeel moet vormen over het toekomstig gedrag en over de toekomstige bekwaamheid van de kandidaten. ${ }^{81}$ Als men "bekwaamheid" echter uitsluitend opvat als "cognitieve bekwaamheid", en niet als substantiële politieke bekwaamheid, dan heeft de kiezer bij een volksraadpleging in elk geval minder hulpmiddelen ('cues') ter beschikking om tot een keuze te komen.

Naast het aspect van de cognitieve bekwaamheid die zowel bij een opiniepeiling als bij een volksraadpleging of referendum nodig is om een keuze te maken, kan men op enkele grondige verschillen wijzen die alle van aard zijn om te veronderstellen dat de effecten van een vraagstelling bij referendums en volksraadplegingen kleiner zijn dan bij opiniepeilingen.

Bij een opiniepeiling wordt men plots geconfronteerd met een vraag zonder dat men de tijd had om daarover na te denken of om informatie te zoeken die nuttig kan zijn bij het opmaken van een antwoord. Bij een volksraadpleging zijn de vragen die voorgelegd worden een ruime tijd vooraf in omloop, er is een publieke discussie, er wordt informatie gegeven, en de deelnemer kan zich in discussie met significante anderen een opinie vormen. Ook zijn het formaat van de vraag en de antwoordmoge-

${ }^{77}$ P. KRIESI en D. BÜTSCHI, Opinion formation and change. The case of the Swiss policy against air pollution caused by cars. Department of Political Science, University of Geneva (onderzoeksrapport), 1999, 161. In dit onderzoek varieert het aantal respondenten met een stabiele opinie tussen $40 \%$ en $65 \%$.

${ }^{78}$ Ibid., 286-287.

${ }^{79}$ In een aantal gevallen wordt natuurlijk gekozen omwille van de gewoonte en traditie, met name $13 \%$ van de deelnemers in 1995. Dat is evenveel als omwille van de opvoeding of identificatie. Zie: M. SwYNGEDOUw, R. BEERTEN en J. BILLIET, Les motivations électorales en Flandre, 21 mei 1995. Courrier hebdomadaire CRISP nr. 1557, 1997, 15.

${ }^{80}$ D.B. MAGLEBY, o.c. $1994,248-249$.

${ }^{81}$ J. VERHULST, o.c. $1998,119$. 
lijkheden vooraf bekend. De vorming van een opinie en zelfs het opmaken van het antwoord gebeurt dus vooraf. Enkel het neerschrijven van het antwoord heeft op het moment van de bevraging plaats. Het is zelfs zo dat mogelijke bronnen van misleiding in de vraagstelling vooraf kunnen opgemerkt en onder de aandacht van de deelnemers kiezer gebracht worden. ${ }^{82}$

Vermoedelijk zal men bij een volksraadpleging meer bedachtzaam zijn bij het neerschrijven van een antwoord dan dit bij een enquête het geval is. Het gaat immers niet zomaar om een vrijblijvend antwoord op een opinievraag maar over een act waar beleidsconsequenties aan verbonden zijn. Dit maakt dat de ondervraagde bij een volksraadpleging zich meer van de ernst van zijn antwoord bewust is

Om die redenen mag men verwachten dat sommige response effecten minder kans hebben om op te treden bij een referendum of volksraadpleging. Dit is bijvoorbeeld het geval voor de vermelde response sets. Andere invloeden die werden behandeld bij de meerkeuzevragen en bij de "ja/neen" zijn echter ook voor referendumvragen van toepassing.

We kunnen in dit verband nogmaals wijzen op de bevindingen van Holleman. De keuze bij een eenvoudige "ja/neen" (of "eens/oneens") vraag wordt beïnvloed door het onderliggend glijdend karakter van de antwoordschaal (van sterk voor tot sterk tegen) gekoppeld aan één of ander werkwoord dat connotaties oproept. Dit kan toegepast worden op het correctief referendum dat in Amsterdam werd gehouden met betrekking tot een gemeentelijk besluit inzake een tramtracé. ${ }^{83}$ Het gebruik van het werkwoord "vasthouden aan" (een besluit) zou het, omwille van de gematigde betekenis van het woord, voor de ondervraagde moeilijker maken om de betekenissen van "ja" en "neen" te onderscheiden. Daarentegen is het werkwoord "intrekken" (van een besluit) extremer, gegeven dat een instantie veel tijd besteed heeft om tot een besluit te komen. Men kan verwachten dat een kleiner aantal ondervraagden "ja" zal zeggen tegen intrekken dan "neen" tegen handhaven. Dit zou nog meer het geval zijn indien men het woord "vernietigen" zou gebruiken. Het zullen dan wel de fervente tegenstanders zijn die "ja" zullen antwoorden, terwijl een grotere groep geneigd zal zijn om "neen" te antwoorden. De vraag is hier natuurlijk wie de beslissing neemt bij de keuze van het werkwoord.

Dit voorbeeld toont aan hoe het wisselen van een kwalificerende dimensie (een tegengesteld werkwoord) in een vraagtekst tot een andere verdeling van eens (ja) of oneens (neen) zal leiden. Dit onderzoek leert dat bij eenvoudige keuzevragen van het type "ja/neen", afgezien van de neiging tot beamen ook nog een ander response effect kan hebben. Hierbij speelt enerzijds de positie van de ondervraagde op de onderliggende attitude een rol, en kan de keuze verschillen naargelang het om een uitgesproken of extreme houding gaat dan wel een zwakke of gematigde houding, en anderzijds de connotatie die vast hangt aan de gebruikte bepalende woorden in de vraagtekst. De antwoordverdelingen die men bekomt zijn dus gevoelig voor wijzigingen in de vraagtekst. Bij opinieonderzoek wordt dit opgelost door een onderliggende houding te meten via een set van indicatoren die variëren in verwoording. ${ }^{84}$ Zo kan men de ware score schatten in een populatie en zicht krijgen op de "meetfouten" omwille van

${ }^{82}$ G. DE GEEST, o.c. 1986, 13; zie ook: J. VeRHULST, o.c. 1998, 136 in verband met het Belfort referendum in Get. Dank zij de campagne wisten de burgers we l degelijk hoe ze hun stem moesten uitbrengen ondanks de verwarrende vraagstelling waarbij de tegenstanders van de Belfort-parking "ja" moesten stemmen.

${ }^{83}$ B. HollemAN, o.c. 2000, 214-215. De bepalende woorden ('qualifiers') in de complexe vraagstelling van dit referendum zijn "vasthouden aan" en "handhaven" ("Bent U het eens/oneens met het raadsbesluit vast te houden aan zijn besluit van 21 April 1993, nr. 227 (Gemeenteblad afd. 1, blz. 10057), inzake het handhaven van de reservering voor een tramtracé recht door het weilandje de Vrije Geer in de richting van de Middelveldsche Akerpolder. Eens met dit raadsbesluit/oneens met dit raadsbesluit". Mogelijke contradictoire werkwoorden ('qualifiers') zijn "vernietigen", "herroepen" of "intrekken".

${ }^{84}$ Zie hiervoor o.m. W.E. SARIS en M. AKOs (Eds.), The Multitrait-Multimethod Approach to Evaluate Measurement Instruments. Budapest, Eötvös University Press, 1995; W.E. SARIS, Design and models for quality assessment of survy measuses, in W. SARIS en M. AKOs (Eds.), The Multitrait-Multimethod Approach to Evaluate Measurement Instruments. Budapest, Eötvös University Press, 1995, 9-37. 
specifieke verwoordingen. In een volksraadpleging moet men het doen met één indicator waardoor het niet mogelijk is om een idee te hebben van de meetfout.

\section{B. Hoe groot zijn de te verwachten effecten?}

Om die vraag te beantwoorden is het nodig om nogmaals het onderscheid tussen systematische fouten (effecten) en toevallige fouten (cfr. infra) onder de aandacht te brengen. In het opinieonderzoek wordt gepoogd om via informatie over deze fouten de ware verdeling te schatten aan de hand van de geobserveerde verdeling. ${ }^{85}$ Uit onderzoek m.b.t. meetfouten in opinieonderzoek blijkt dat de toevallige en systematische meetfouten bij aparte items aanzienlijk qua omvang zijn. Verschillen van tien tot twintig procentpunten zijn niet uitzonderlijk. De stabiliteit van de antwoorden zoals deze gemeten worden via test-retest correlaties, is laag. Dit wijst er op dat nogal wat ondervraagden van de ene bevraging naar de andere hun antwoord wijzigen. Natuurlijk is dit niet helemaal toe te schrijven aan toevalsfouten (onbetrouwbaarheid) vermits werkelijke verandering en verschillen in het instrument niet helemaal uit te sluiten zijn. Het blijkt dat de stabiliteit aanzienlijk groter is bij hoger geschoolden en bij ondervraagden met een uitgesproken opinie en veel belangstelling voor het onderwerp, dan bij lager geschoolden en ondervraagden zonder uitgesproken opinie en minder belangstelling. De stabiliteit is eveneens groter voor concrete onderwerpen die sterk in de belangstelling staan, bij onderwerpen waarmee de ondervraagde vertrouwd is en bij eenvoudige vragen, dan bij vage algemene onderwerpen en complexe vragen. ${ }^{86}$. Laten we even het mogelijk effect van toevallige en systematische fouten bekijken:

De vraagstelling in een volksraadpleging is doorgaans eenvoudiger wat de antwoordschaal aangaat ("ja" of "neen"). De antwoorden op zulke vragen zijn meer betrouwbaar dan antwoorden op langere en meer complexe antwoordschalen, maar toch kan ook hier onbetrouwbaarheid als gevolg van toevallige fouten, niet uitgesloten worden. Maar zelfs indien de onbetrouwbaarheid nog een pak groter zou zijn dan de 5\% die onderzoekers als zeer aanvaardbaar beschouwen dan is dit bij een volksraadpleging met een "ja/neen" vraag niet zo problematisch omdat alleen de geaggregeerde gegevens van betekenis zijn (de globale verdeling van de antwoorden). De toevallig foute antwoorden op niveau van de individuen hebben vaak niet zoveel effect op de totale antwoordverdelingen. Als het werkelijk om onbetrouwbaarheid gaat, dan zijn de fouten immers toevallig, en dan is de kans dat deze optreden even groot voor elke waarde van de 'ware' opinie (voor of tegen). ${ }^{87}$ Indien de twee kampen ongeveer even groot zijn, dan heffen de fouten elkaar op. Indien de verdeling heel scheef is met veel meer voorstanders dan tegenstanders, dan zullen er méér zijn die fout "neen" antwoorden dan fout "ja", maar slechts in uitzonderlijke gevallen zal daardoor de uitslag wijzigen. ${ }^{88}$

\footnotetext{
${ }^{85}$ Zie hiervoor J. BLLIET, op cit. 2000, 281-282.

${ }^{86}$ Zie hiervoor J. BLLLET, o.c. 2000, 250-251; J.R. ZALLER, o.c. 1992, 31-34. In een panel studie met vier golven in Zwitserland stelden Kriesi en Bütschi vast dat tussen 17\% (autovrije zone) en 27\% (CO2 tax) van de ondervraagden twee tot drie keer van opinie wijzigden. In de periodes tussen de golven waren er echter meerdere evenementen i.v.m. het milieu, zoals o.m. een referendumcampagne, maar de onderzoekers nemen toch aan dat het in het geval van voortdurend veranderen voor een aanzienlijk deel om toevallige fouten gaat (onbetrouwbaarheid). Zie: P. KRIESI en D. BÜTSCHI, o.c. 1999, 198-117.

${ }^{87}$ Toevalsfouten zijn per definitie niet systematisch, en bijgevolg zijn ze onafhankelijk van de ware scores. Indien ze wel zouden samenhangen met de ware scores, dan zou er immers een systematiek insteken, en gaat het niet meer over toevalsfouten.

${ }^{88}$ Laten we het voorbeeld nemen van een volksraadpleging met 100.000 deelnemers. Neem dat in de werkelijkheid 55\% voor de maatregel is en $45 \%$ tegen, en veronderstel een betrekkelijk grote onbetrouwbaarheid van 20\%. In dat geval zal 20\% van de 55.000 voorstanders "neen" antwoorden (een foutief antwoord, dat is 11.000 ). Anderzijds zijn er bij de tegenstanders eveneens $20 \%$ die "ja" antwoorden (dat is 9.000). Bijgevolg is de waargenomen uitslag 53.000 versus 47.000 , dit is $53 \%$ versus $47 \%$. Het maakt dus niet geen verschil voor de politieke betekenis van de uitslag.
} 
Anders is het natuurlijk gesteld met effecten van de vraagstelling die we hebben besproken. Hier gaat het steeds om invloeden die systematisch in de ene of andere richting gaan. In de mate dat het antwoord dat de ondervraagde geeft, afwijkt van de 'ware' opinie, kunnen we ook hier van meetfouten spreken. De omvang van de meeste effecten is bekend. Zulke effecten resulteren vaak in verschillen in marginale verdeling die tussen de 10 en 20 procentpunten bedragen. Er zijn zelfs voorbeelden van response effecten van méér dan 30 procentpunten, maar dat is dan wel uitzonderlijk ${ }^{89}$. Deze aanzienlijke effecten hebben echter betrekkingen op de context van meerdere vragen en op vragen die qua structuur en antwoordmogelijkheden veel complexer zijn dan"ja/neen" vragen. De effecten bij de besproken "ja/neen" vragen m.b.t. "verbieden/niet toelaten" bedragen gemiddeld 14,2 procentpunten (standaardafwijking van 9,85). ${ }^{90}$ Zulke effecten zijn echter gemeten t.o.v. een andere variant van de gestelde vraag. Het 'ware antwoord' is niet bekend zodat de fout, in de betekenis van verschil tussen geobserveerd percentage en 'waar' percentage, geringer is dan het effect. In tegenstelling tot de onbetrouwbaarheid kunnen systematische response effecten in het geval dat de twee kampen niet heel veel van elkaar verschillen wél een wijziging van de uitslag (meerderheid wordt minderheid) voor gevolg hebben.

\section{Welke instantie kan over de kwaliteit van de vraagstelling waken?}

Aan welke kwalitatieve vereisten moet de vragen in referenda en volksraadplegingen voldoen en welke instantie moet daarover waken? Het antwoord op deze vraag werd reeds gedeeltelijk gegeven in wat voorafgaat. Er werden een aantal strikte beperkingen opgelegd en er werd ook gewezen op een aantal fouten die moeten vermeden worden.

In zover duidelijke en onbetwistbare regels bestaan over het formuleren van vragen in referenda en volksraadplegingen, moeten deze natuurlijk toegepast worden. Maar daarmee is het antwoord op de vraag niet volledig rond. Vaak ontbreken immers duidelijke regels voor situaties waar effecten vermoed kunnen worden. De reden hiervan is eenvoudig: elke vraag heeft effect op de antwoorden en in een aantal gevallen kan men niet bepalen welke vraagvorm het meest geldige antwoord verschaft. Waar dit gegeven in een opiniepeiling kan aangewend worden om tot een correcte interpretatie ${ }^{91}$ van het resultaat te komen, is dit uitgesloten in een referendum of volksraadpleging. Er is daar immers te weinig bijkomende achtergrondinformatie voorhanden, er worden geen sets van indicatoren gebruikt, en gesplitste steekproeven met meerdere vraagverwoordingen zijn helemaal uitgesloten. In veel gevallen weet men wél dat er problemen zijn, maar men weet niet goed welke oplossing de beste is. Denk bijvoorbeeld aan het door Holleman gesignaleerde probleem inzake de glijdende schaal achter de schijnbaar binaire "ja/neen" antwoordschaal in combinatie met de keuze van een werkwoord. Welk woord moet in dat geval precies gekozen worden: stoppen/verder zetten, handhaven/vernietigen, behouden/intrekken, behouden/herroepen? Alleen ervaring, en in sommige gevallen empirisch onderzoek, kunnen hier uitsluitsel geven.

Het is duidelijk dat de kwaliteit van de vraagstelling alleen maar kan verzekerd zijn indien enerzijds alle betrokkenen zich voldoende bewust zijn van de problemen die zich kunnen voordoen inzake vraagstelling. Deze studie kan daar hopelijk toe bijdragen. Een grotere gevoeligheid bij alle betrokkenen voor de mogelijke problemen die zich kunnen voordoen, zou al een grote stap zijn in de richting van oplossingen. Hiermee zijn we de uitspraak indachtig: "Wie een valstrik wil vermijden, moet weten dat hij bestaat". Daarnaast dient de vraagstelling vanuit een specifieke deskundigheid beoordeeld te

\footnotetext{
${ }^{89}$ Zie J. BILLIET, o.c. 2000, 259-265.

${ }^{90}$ B. Holleman, o.c. 2000, 56-58.

${ }^{91}$ Voor de wijze waarop dit kan gebeuren zie: J. BILLIET, L. WATERPLAS en G. LoOSVELDT, Context Effects as Substantive Data in Social Surveys, in: N. Schwarz en S. Sudman, o.c. 1992, 131-148; Zie ook: J. BILLIET, o.c. $2000,266-275$.
} 
worden. Dit kan geregeld worden via een substantiële controle op de vraagstelling waarbij de kwaliteit van de vraagstelling steeds mede vanuit methodologisch oogpunt wordt bekeken. Zulke controle staat de vrijheid van de burger of van een politieke instantie niet in de weg, ze is integendeel precies nodig om de kwaliteit van de vraagstelling vanuit democratisch oogpunt te optimaliseren. De vraagstelling moet geldig zijn, d.i. ze moet meten wat ze beoogt te meten. Hoe wordt dit toezicht best georganiseerd?

In de huidige praktijk hebben doorgaans staatsrechtelijke instellingen het laatste woord inzake vraagstelling. In 1986 vermeldt De Geest dat, voor zover hij kon nagaan, nergens ter wereld gebruik wordt gemaakt van een neutrale instanties die over de vraagstelling oordeelt. Toch wordt daar in publicaties vrijwel unaniem voor gepleit. ${ }^{92}$ Wat België aangaat, suggereert De Geest de Raad van State of het Arbitragehof als mogelijke neutrale instanties die over de vraagstelling kunnen oordelen. De Geest laat ook de mogelijkheid van een speciale Referendum Commissie open. ${ }^{93}$ Zulke commissie is voorzien in het kader van de gemeentelijke volksraadplegingen.

De Vlaamse Adviescommissie voor volksraadplegingen werd opgericht bij besluit van de Vlaamse regering op 8 juni 1997 en werd effectief opgestart op 8 maart 1998. Zij bestaat uit vijf leden. Volgens het oprichtingsbesluit wordt het voorzitterschap waargenomen door een magistraat bij de Raad van State. Verder bestaat de Adviescommissie uit twee hoogleraren van de Vlaamse universiteiten en twee ambtenaren van de Vlaamse gemeenschap die deskundig zijn op gebied van het administratief recht. Een ambtenaar neemt (deeltijds) het secretariaat waar. De Adviescommissie heeft een eerder beperkte opdracht. Zij verstrekt niet-bindende adviezen aan de Vlaamse minister van Binnenlandse Aangelegenheden in het kader van de uitoefening van het administratief toezicht over gemeentelijke volksraadplegingen. De gemeentebesturen zijn niet verplicht om een voorafgaandelijk advies te vragen. Zij kunnen vrijwillig een vraag voor advies voorleggen. Ook particulieren kunnen zich tot de Adviescommissie richten met vragen om advies of concrete klachten. Met de minister werd een werkafspraak gemaakt dat de Adviescommissie zich met het oog op een advies buigt over elk probleem in verband met de toepassing van de wetgeving inzake volksraadplegingen. De Adviescommissie heeft een huishoudelijk reglement opgesteld waarin de interne werkwijze wordt geregeld. In dit reglement is bepaald dat alle adviezen gemotiveerd en openbaar moeten zijn. ${ }^{94}$

Over de mogelijkheid van een controle over de vraagstelling werd in een hoorzitting van het Vlaams Parlement van gedachten gewisseld naar aanleiding van de Gentse volksraadpleging van 14 december 1997. Daaruit blijkt dat de Adviescommissie zich reeds in minstens één geval op vraag van een gemeente (St.- Niklaas) heeft uitgesproken over de vraagstelling, en dat zij een gewijzigde vraagstelling heeft voorgesteld. ${ }^{95}$ Verder blijkt uit de hoorzitting dat diverse actoren er voorstander van zijn dat de Adviescommissie zich over de vraagstelling zou uitspreken. Zo is de voorzitter van de Adviescommissie van oordeel dat inzake de vraagstelling een grotere rol aan de Adviescommissie zou kunnen worden toebedeeld. Momenteel kan zij enkel een niet-bindend voorstel van vraagstelling uitbrengen. Volgens de voorzitter zou men kunnen werken met een orgaan (de Adviescommissie of een Hoge Raad die bijvoorbeeld uitgebreid wordt met het betrokken gemeentebestuur) die dwingend de vraagstelling oplegt. ${ }^{96}$ Volgens de toenmalige Minister van Binnenlandse Aangelegenheden moet, omwille van de complexiteit van de onderwerpen die bevraagd worden, de mogelijkheid worden geboden om voorafgaandelijk met de Advies-

\footnotetext{
${ }^{92}$ Ibid., 19. De Geest verwijst o.m. naar de werken van P.C. GiLhUIS, o.c. 1981; S. ANDERSON, Yes or nay? Referenda in the United Kingdom. London, Cassell, 1975; A.D. BELIFANTE, De burger en zijn staat. Alphen aan den Rijn, 1966.

${ }^{93}$ Ibid., 20.

${ }^{94}$ Uitleg over de Adviescommissie door de heer Peter Sourbron, voorzitter n.a.v. de hoorzitting van 8 juli 1998 in het Vlaams Parlement. Zie: Vlaams Parlement. Stuk 1115, 1 (1997-1998), 8.

${ }^{95}$ Vlaams Parlement. Stuk 11115, 1 (1997-1998), 8.

${ }^{96}$ Ibid., 8.
} 
commissie te overleggen over de vraagstelling, waarna de Adviescommissie eventueel kan corrigeren en een ander voorstel formuleren.

Het toevertrouwen aan een Adviescommissie of een Hoge raad van de controle over de vraagstelling met het oog op het uitsluiten van manipulatie en het zo duidelijk mogelijk verwoorden van een vraag die in overeenstemming is met de wensen van de initiatiefnemers, dient zeker in overweging genomen te worden om de geschetste problemen inzake vraagstelling het hoofd te bieden. Kan zulke commissie controle uitoefenen over diverse aspecten van de vraagstelling? Welke voorwaarden moeten vervuld zijn opdat een referendumcommissie haar taak dienaangaande adequaat kan vervullen? Ik zie een drietal voorwaarden.

(1) Opdat een commissie op een adequate wijze controle zou kunnen uitoefenen op de vraagstelling moet vanzelfsprekend in de schoot van zo'n commissie bij alle leden een algemene gevoeligheid bestaan voor het probleem van de vraagstelling. Men moet in staat zijn om de mogelijke effecten van de vraagverwoording te onderkennen.

(2) Met het oog op het waken over de toepassing van standaardregels inzake de vraagstelling en met het oog op het nemen van de juiste beslissingen is, bij gebrek aan pasklare regels, een grondiger onderzoek naar een vraagstelling nodig is. Om daarover te kunnen oordelen moet binnen de commissie minstens één van de leden over een specifieke deskundigheid inzake de vraagstelling beschikken. $^{97}$

(3) Het kan zijn dat een probleem inzake vraagstelling uitzonderlijk niet kan opgelost worden binnen de schoot van een commissie, en dat een meer uitvoerige procedure op gang moet worden gebracht. De betreffende commissie moet in staat zijn om hierover een adequate beslissing te nmen. Deze beslissing kan bestaan in het raadplegen van externe experts of, uitzonderlijk, het laten uitvoeren door kleinschalig cognitief onderzoek met het oog op een correcte vraagstelling. ${ }^{98}$

.Het zou niet ernstig zijn om te beweren dat het toepassen van de hier voorgestelde maatregelen zou leiden tot het ontwerpen van perfecte vragen die onbetwistbaar in staat zijn de 'ware' opinies en keuzen van de bevolking naar boven te halen. Waarom is deze aandacht voor de vraagstelling dan wél nodig? Deze aandacht voor de vraagstelling moet waarborgen dat alles in het werk wordt gesteld om het peilen naar de voorkeur van de bevolking zo ernstig en eerlijk mogelijk verloopt. Het doel van volksraadplegingen is het beter betrekken van de bevolking bij de democratische besluitvorming. De aandacht voor een zo betrouwbare en geldig mogelijke vraagstelling draagt daar toe bij.

\footnotetext{
${ }^{97}$ Momenteel is één van de academische leden een politoloog.

${ }^{98}$ Sinds ongeveer een decennium worden in de methodologie van het opinieonderzoek zgn. cognitieve interviews gebruikt om problemen inzake vraagverwoording vast te stellen en zo mogelijk op te lossen. Deze problemen hebben betrekking op het begrijpen van de vraag en de gebruikte temen zoals ze bedoeld werden en op het vaststellen van cognitieve problemen bij het beantwoorden van de vraag. Cognitieve interviewen hebben plaats bij een beperkt aantal adequaat geselecteerde ondervraagden (een twintigtal) die ofwel in een zgn. vragenlabo ofwel bij hen thuis grondig bevraagd worden. Zie: B.H. FORSYTH en J.T. LESSLER, Cognitive Laboratory Methods: a Taxonomy, in P.P. BIEMER et al. (Eds.), Measurement Errors in Surveys. New York, John Wiley en Sons, 1991, 393-418; S. Sudman, N. BradBuRn en N. SchwarZ, Thinking about Answers. The Application of Cognitive Processes to Survey Methodolgy. San Francisco, Jossey Bass, 1996, 16-17; N.C. SCHAEFFER en D.W. MaYnARD, From Paradigm to Prototype and Back Again. Interactive Aspects of Cognitive Processing in Standardized Interviews, in N. Schwarz en S. Sudman (Eds.), Answering Questions. Methodology for Determining Cognitive and Communicative Processes in Survey Research. San Francisco, Jossey Bass Pub, 1996, 6588. Voor een gebruik in België zie: K. NUYTS, G. LOOSVELDT en J. BILLIET, Het gebruik van cognitieve interviewtechnieken bij het ontwikkelen en testen van meetinstrumenten voor survey-onderzoek, in: Tijdschrift voor Sociologie, 18, (1997), 4, 475-500.
} 


\section{Besluit}

Los van mogelijke beschouwingen aangaande het referendum en de volksraadpleging vanuit het oogpunt van wat volgens mij een essentieel kenmerk van de democratie is, - communicatie met het oog op het bereiken van overeenstemming tussen burgers in allerhande verbanden, - heb ik gepoogd om op een zakelijke wijze het probleem van de vraagstelling te behandelen. Uit wat voorafgaat zal wel duidelijk geworden zijn dat vanuit het oogpunt van de vraagstelling en het 'meten' van een voorkeur in een bevolking, het instrument van het referendum of de volksraadpleging heel omzichtig moet gebruikt worden. Er kan veel mis gaan. Deskundigheid op het gebied van het onderzoek naar de effecten van de vraagverwoording, heeft hier zeker iets te bieden. Wij hebben de indruk dat dit te veel over het hoofd wordt gezien bij de discussie over iets wat toch in essentie het beantwoorden van een opinievraag is. Wat de moeilijkheden ook mogen zijn, vanuit het aspect van de vraagstelling blijft een referendum of volksraadpleging mogelijk en kan men dit instrument niet afwijzen.

Er zijn wel enkele strikte voorwaarden wat het type van vragen aangaat. Het is duidelijk dat open vragen absoluut uitgesloten zijn. Kan men naast "ja/neen" vragen ook meerkeuzevragen gebruiken, en mogen vragen meerdere onderwerpen tegelijk aangeboden worden?

Het is bij een referendum en een volksraadpleging niet aangewezen om meerkeuzevragen te gebruiken omwille van de besproken moeilijkheden van het onbetwistbaar vaststellen van de meerderheid. Deze beperking tot "ja" en "neen" vragen wordt onderschreven in de wet en de besluiten m.b.t. de provinciale en gemeentelijke volksraadplegingen in België. In de nadere bepalingen wordt zelfs geregeld hoe het papier en de stemvakken er uit moeten zien. "J9 "Ja" en "neen" vragen kunnen nog van een verschillend type zijn. ${ }^{100}$ Ofwel gebruikt men een vraagvorm waarin impliciet met een "ja" of een "neen" kan worden geantwoord. Ofwel gebruikt men een vorm waarin het toegelaten is te antwoorden met "eens" en "oneens" of een equivalent conceptenpaar. In dit laatste geval kan de vraagvorm gebalanceerd zijn, d.w.z. dat de keuze expliciet in de vraagstelling wordt vermeld ("bent $U$ het er mee eens of oneens dat..."). Het is in elk geval aanbevolen om de vraag zo éénduidig en zo eenvoudig mogelijk te maken en dan lijken "ja" en "neen" de beste keuze. Vanuit het oogpunt van een eenvoudige berekening van een meerderheid zou men ook de gedwongen keuze voor twee alternatieven kunnen toestaan ("kiest $U$ voor A of kiest $U$ voor B?", maar hier zijn dan zoveel andere effecten mogelijk dat dit best vermeden wordt, onder meer het probleem van het gemanipuleerd keuzealternatief. ${ }^{101}$

Sommigen zouden kunnen opwerpen dat het toch mogelijk zou moeten zijn om vragen met meerdere keuzealternatieven te gebruiken. Zulke vragen hebben het voordeel dat ze meer informatie bevatten en dat ze een meer genuanceerde keuze mogelijk maken. Er werd echter aangetoond dat er dan tal van problemen ontstaan, zoals volgorde effecten of het moeilijk onbetwistbaar vaststellen van een meerderheid. Deze meer soepele opstelling met betrekking tot meerkeuzevragen zou kunnen ingegeven zijn door het argument dat een volksraadpleging niet in dezelfde mate bindend is, maar veeleer

${ }^{99}$ Zie: Wet van 10 april 1995 tot aanvulling van de nieuwe gemeentewet met bepalingen betreffende de $\mathrm{g} e-$ meentelijke volksraadpleging, art. 307 (p. 10351, BS 21.041995); K.B. van 19 april 1999 tot vaststelling van de nadere procedureregels voor het houden van een gemeentelijke volksraadpleging, art. 5 (p. 1019, BS 01.07.1999); Wet van 25 juni 1997 tot wijziging van de provinciewet, de wet van 1 juli 1960 tot wijziging van de provinciewet en de gemeentewet wat betreft de eedaflegging en de wet van 19 oktober 1921 tot regeling van de provincieraadsverkiezingen, art. 75 (p. 13352, BS 22.04.1999); KB van 7 juli 1999 tot vaststelling van de nadere procedureregels voor het houden van een provinciale volksraadpleging, art. 6 (p. 31950, BS 28.08.1999).

${ }^{100}$ N.J. MolenaAR en J.H. SMIT, Asking and answering yes/no questions in survey interviews: a conversational approach, in: Quality and Quantity, 30 (1996), 120-122.

${ }^{101}$ Bijvoorbeeld een niet reëel alternatief, suggestie, een categorie die beide afwijst zodat men dan een meerkeuzevraag heeft. 
een poging om de wensen van de bevolking zo goed mogelijk in te schatten ${ }^{102}$. Hier ligt echter een brede marge voor manipulatie. In dit geval moet in elk geval de wijze van tellen (vaststellen van de meerderheid) op voorhand duidelijk bekend zijn en buiten discussie staan. Bovendien zal de vraagstelling vooraf steeds zeer grondig en met een deskundig oog moeten bekeken worden. Uitzonderlijk kan het nodig zijn alternatieve vraagstellingen aan een empirisch onderzoek te onderwerpen.

Omwille van het gesignaleerde gevaar van context effecten is het ook niet aangezen om in een referendum of volksraadpleging meerdere thema's samen te behandelen. Bovendien is uit onderzoek gbleken dat de deelname aan volksraadplegingen lager is indien ze over meerdere uiteenlopende thema's gaan. In geval het om meerdere onderwerpen gaat is het debat vaak verward en oppervlakig zodat de burgers zich geen duidelijke mening kunnen vormen. Indien men toch de opinie of keuze uit meerdere onderwerpen wenst te kennen, dan kan men beter een ernstig en wetenschappelijk uitgevoerde opiniepeiling overwegen. ${ }^{103}$

Tenslotte is tussen de lijnen van deze studie wellicht ook duidelijk geworden dat een referendum of volksraadpleging van waarde is in de mate dat het voorafgaand openbaar gesprek degelijk wordt georganiseerd. Een ernstige campagne waarin alle overwegingen pro en contra en alle consequenties aan bod komen, is een essentiële voorwaarde voor het democratisch gehalte van dit instrument. Daar is zeker een rol weggelegd voor o.m. het 'middenveld'. ${ }^{104}$

\footnotetext{
${ }^{102}$ Hierbij moet vermeld worden dat een wetenschappelijk uitgevoerde opiniepeiling onder een aantal strikte voorwaarden geschikter is dan een volksraadpleging om een goed zicht op de keuzen en opinies van de bevolking te krijgen. Een volksraadpleging heeft echter het voordeel dat alle burgers reëel de kans hebben om zich vrijwillig over iets uit te spreken, bij een peiling gaat het steeds om een steekproef waarin bij de trekking elke burger meestal eezelfde kans heeft om opgenomen te worden in de steekproef, maar niet bij de bevraging als zodanig. Andere verschillen in het voordeel van volksbevragingen hebben te maken met de gerichte informatiecampagne die een opinievormende waarde kan hebben.

103 Zie hiervoor BILLIET, o.c. 2000.

${ }^{104}$ Zie bijvoorbeeld voor de eerste volksraadplegingen in België daarover: W. DEWACHTER, Het referendum zal aan de Belgische politieke besluitvorming voorbijgaan, in: W. VAN DER BIESEN (Ed.), Wetenschap en Journalistiek. Leuven, Cecowe, 1980, 83-92; A. LAPORTE, Referendum in Andenne en Tessenderlo, in: Res Publica, 3 (1979), 515-530.
} 